Article

\title{
Synthesis and Antibacterial Evaluation of New Sulfone Derivatives Containing 2-Aroxymethyl-1,3,4-Oxadiazole/Thiadiazole Moiety
}

\author{
Shihu Su ${ }^{1,2}$, Xia Zhou ${ }^{1, *}$, Guoping Liao ${ }^{1}$, Puying Qi ${ }^{1}$ and Linhong Jin ${ }^{1, *}$ \\ 1 State Key Laboratory Breeding Base of Green Pesticide and Agricultural Bioengineering, Key Laboratory of \\ Green Pesticide and Agricultural Bioengineering, Ministry of Education, Research and Development Center \\ for Fine Chemicals, Guizhou University, Guiyang 550025, China; happytt365@foxmail.com (S.S.); \\ lgp899017@163.com (G.L.); qpuying000@163.com (P.Q.) \\ 2 Zunyi Agricultural Products Quality and Safety Inspection and Testing Center, Room 698, Shanghai Road, \\ Huichuan District, Zunyi 563000, Guizhou, China \\ * Correspondence: zhouxia_j@126.com (X.Z.); linhong_j@126.com (L.J.); Tel.: +86-851-362-0521 (X.Z. \& L.J.); \\ Fax: +86-851-362-2211 (X.Z. \& L.J.)
}

Academic Editor: Panayiotis A. Koutentis

Received: 21 November 2016; Accepted: 27 December 2016; Published: 31 December 2016

\begin{abstract}
Sulfones are one of the most important classes of agricultural fungicides. To discover new lead compounds with high antibacterial activity, a series of new sulfone derivatives were designed and synthesized by introducing the aroxymethyl moiety into the scaffold of 1,3,4-oxadiazole/thiadiazole sulfones. Antibacterial activities against three phytopathogens (Xanthomonas oryzae pv. oryzae, Ralstonia solanacearum, Xanthomonas axonopodis pv. citri.) were assayed in vitro. As compared to the control of commercial fungicides and some reported sulfone fungicides, seven compounds 5I-1-5I-7 exerted remarkably higher activities with $\mathrm{EC}_{50}$ values ranging from $0.45-1.86 \mu \mathrm{g} / \mathrm{mL}$ against $X$. oryzae and $1.97-20.15 \mu \mathrm{g} / \mathrm{mL}$ against $R$. solanacearum. Exhilaratingly, 5I-1, 5I-2 and 5I-4 displayed significant in vivo activity against $X$. oryzae with protective effect of $90.4 \%, 77.7 \%$, and $81.1 \%$ at $200 \mu \mathrm{g} / \mathrm{mL}$, respectively, much higher than that exhibited by Bismerthiazol (25.6\%) and Thiadiazole-copper $(32.0 \%)$. And the differential phytotoxicity of active derivatives was preliminarily checked. The results demonstrated that derivative of 2-aroxymethyl-1,3,4-oxadiazole/thiadiazole sulfone can serve as potential alternative bactericides for the management of plant bacterial diseases.
\end{abstract}

Keywords: synthesis; 1,3,4-oxadiazole/thiadiazole sulfone; aryloxymethyl; antibacterial activity; structure-activity relationship

\section{Introduction}

Xanthomonas, a large genus of gram-negative plant-associated bacteria, causes important diseases such as bacterial blight of rice by Xanthomonas oryzae pv. Oryzae (X. oryzae) and citrus canker by Xanthomonas axonopodis pv. citri. (X. axonopodis) leading to serious quality and yield losses in the host crop [1]. Ralstonia solanacearum ( $R$. solanacearum), a soil-borne bacterium, is responsible for bacterial wilt on more than 200 plant species including important crops such as potato, tomato, tobacco and banana [2,3]. Controlling those pathogens with bactericides such as copper based bactericides serves as the most effective way to cure plant disease [4,5]. However, the application of many currently available antibacterial agents is compromised by their low efficiency, phytotoxic effect and high accumulation in the soil [6,7]. For example, Bismerthiazol, one of the major bactericides for the control of rice bacterial leaf blight, only shows the control efficiency of $25.49 \%$ at a high dosage of $200 \mu \mathrm{g} / \mathrm{mL}$ [8]. Furthermore, the emergence of bactericide resistance $[9,10]$ coupled with above drawbacks has led to the rising need for development of high-efficient bactericides to effectively control those agricultural diseases. 
Extensive biochemical studies on sulfone derivatives bearing suitably substituted heterocyclic units have confirmed that those molecular building blocks, as a common pharmacophore model are effective against various phytopathogens in agriculture [11-13]. In this regard, many bactericidal agents based on heterocyclic sulfones have been patented and employed for crop protection [4,12-16]. For example, 1,3,4-oxadiazole/thiadiazole bearing sulfone derivatives showed potent antibacterial activities against $X$. oryzae and $R$. solanacearum [4]. We have sought new synthetic compounds related to phenyl/benzyl substituted 1,3,4-oxadiazole sulfone that have similar antibacterial action $[4,15,16]$. Quite interestingly, it was demonstrated that replacement of phenyl group with benzyl fragment at the 2-position of the 1,3,4-oxadiazole/thiadiazole unit (Figure 1) could significantly enhance the flexibility of the molecular backbone to combine with the receptor protein of pathogenic bacteria $[14,15]$. Another evidence indicated that the incorporation of an aroxymethyl group to the heterocyclic component can serve as an effective approach for enhancing antibacterial activity [17]. Intriguingly, in the course of structure optimization, the modifying of the oxime ether pharmacophore (strobilurins) with a phenoxymethyl side chain lead to the successful landing of Kresoxim-methy [18]. Fascinated by these investigations, herein we explored to build the heterocyclically substituted sulfones incorporating an aroxymethyl fragment with -O-attached to the heterocycle through linker $\left(-\mathrm{CH}_{2}-\right)$. The design strategy and synthetic route are schematically depicted in Figures 1 and 2 respectively. In our synthetic design, the aroxymethyl group involved is typical and expected to play an important role in increasing bioactivity. The inhibitory activity of target compounds on growth of various important pathogenic bacteria in vitro and in infected rice were investigated and their structure-activity relationships (SARs) were discussed. Phytotoxicity in tobacco leaves and rice seed were also determined.

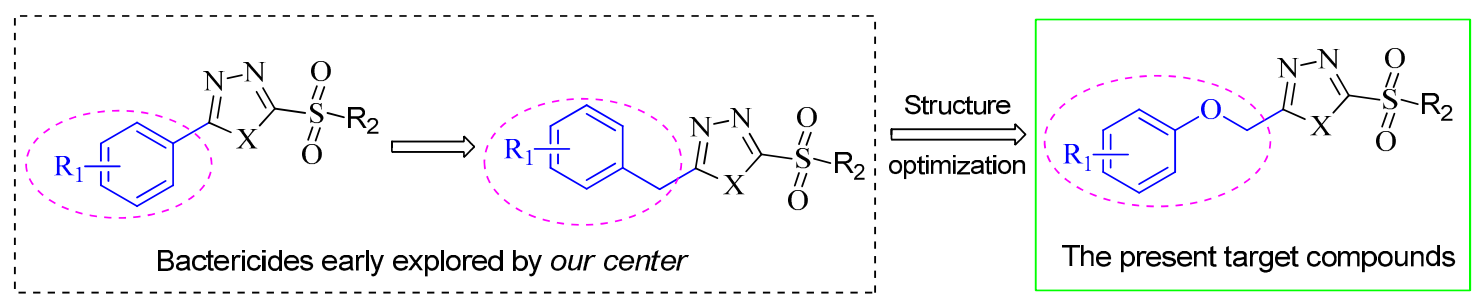

Figure 1. Strategic Design for the Target Compounds.

\section{Results and Discussion}

\subsection{Chemistry}

Compounds $5 \mathbf{I}$ and 5 II were prepared by analogous processes $[17,19,20]$, as presented in Figure 2. Starting from phenol or substituted phenol, the key intermediate 2-aroxymethyl-1,3,4oxadiazole-2-thiol 3 was synthesized in four steps involving esterification [17], hydrazidation, salt formation, and cyclization [19]. Subsequently, thiol 3 was converted into its corresponding thioether derivative 4 by thioetherification with dimethyl/diethyl sulfate or benzyl bromide. Finally, the target sulfonyl oxadiazole/thiadiazole 5I/II was obtained through oxidation of the thioether 4 with potassium permanganate [20]. The structures of all the target compounds were characterized by elemental analyses, and ${ }^{1} \mathrm{H},{ }^{13} \mathrm{C}$ NMR and MS(ESI). 


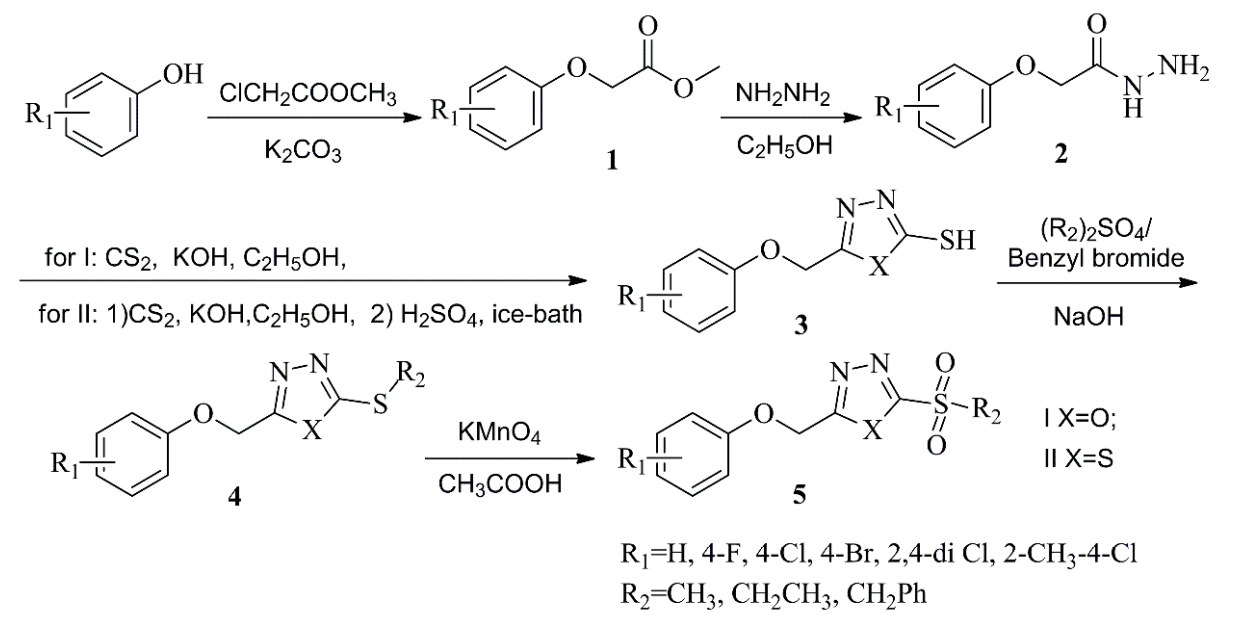

Chemical structures of 5I-1 to $\mathbf{5 I - 1 4}$
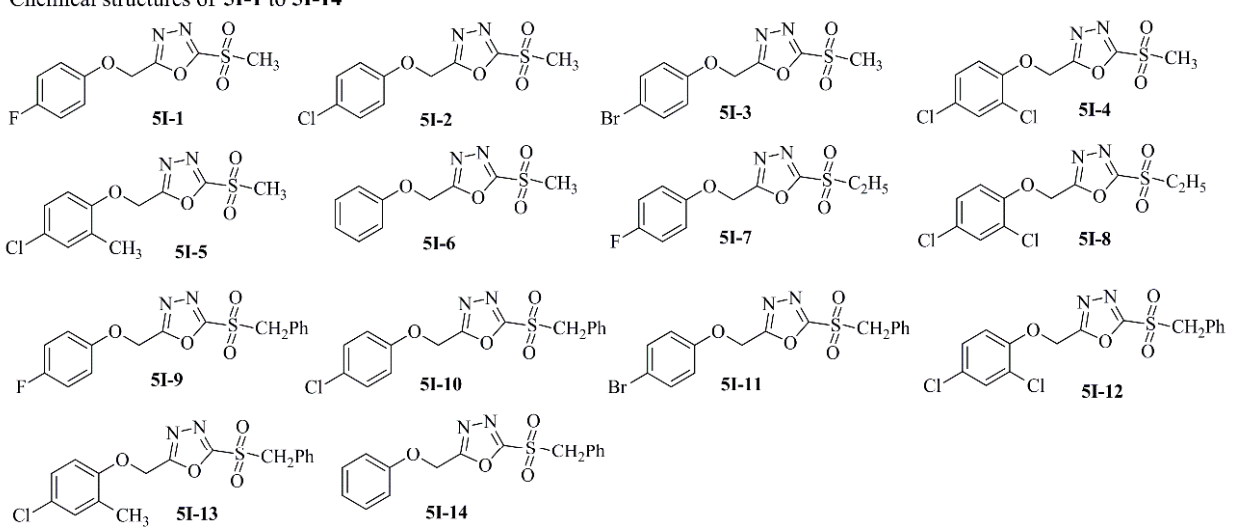

Figure 2. Synthetic Route to the Target Compounds 5I-1-5I-14 and 5II-1-5II-1.

\subsection{In Vitro Antibacterial Activity}

The antibacterial activities of all the compounds were evaluated in vitro against $X$. oryzae, $R$. solanacearum and $X$. axonopodis via the turbidimeter test [21]. To make a judgment on the bactericidal potency of the synthesized compounds, three commercial antibacterials, Bismerthiazol, Kocide 3000 and Thiodiazole-copper were selected as the positive controls. As shown in Table 1, most of the products 5I exhibited better or equivalent antibacterial activities compared to positive controls against the tested plant bacteria. Among them, compounds 5I-1-5I-7 appeared highly active for X. oryzae and R. solanacearum with an observed control efficacy of $100 \%$ both at 200 and $100 \mu \mathrm{g} / \mathrm{mL}$. Interestingly, 5I-1-5I-7 exhibited inhibition rates of $65 \%-100 \%$ at $200 \mu \mathrm{g} / \mathrm{mL}$ and $48 \%-90 \%$ at $100 \mu \mathrm{g} / \mathrm{mL}$ against $X$. axonopodis which were also superior to that of positive controls. On the other hand, the present synthesis and bioactive tests were parallel conducted on 5II. While no anticipated bioactivity was observed, except 5II-1, 5II-2 showed better activities than positive controls against X. oryzae with 
inhibition rates of $84 \%-99 \%$ at $200 \mu \mathrm{g} / \mathrm{mL}$. It was thus confirmed that compounds 5 I bearing 1,3,4-oxidiazole moiety were more potent in combating tested bacteria and displayed significantly higher activity as compared to compounds 5II and positive controls.

Table 1. Inhibition rate of Compounds 5I and 5II against Pathogenic Bacteria X. oryzae, R. solanacearum and $X$. axonopodis a.

\begin{tabular}{|c|c|c|c|c|c|c|c|}
\hline \multirow{2}{*}{ Compd. } & \multirow{2}{*}{$\mathbf{R}_{1} / \mathbf{R}_{2}$} & \multicolumn{2}{|c|}{ X. oryzae } & \multicolumn{2}{|c|}{ R. solanacearum } & \multicolumn{2}{|c|}{$X$. axonopodis } \\
\hline & & $200 \mu \mathrm{g} / \mathrm{mL}$ & $100 \mu \mathrm{g} / \mathrm{mL}$ & $200 \mu \mathrm{g} / \mathrm{mL}$ & $100 \mu \mathrm{g} / \mathrm{mL}$ & $200 \mu \mathrm{g} / \mathrm{mL}$ & $100 \mu \mathrm{g} / \mathrm{mL}$ \\
\hline $5 \mathrm{I}-1$ & $4-\mathrm{F} / \mathrm{CH}_{3}$ & 100 & 100 & 100 & 100 & 80 & 72 \\
\hline $5 \mathrm{I}-2$ & $4-\mathrm{Cl} / \mathrm{CH}_{3}$ & 100 & 100 & 100 & 100 & 88 & 76 \\
\hline $5 \mathrm{I}-3$ & $4-\mathrm{Br} / \mathrm{CH}_{3}$ & 100 & 100 & 100 & 100 & 91 & 90 \\
\hline $5 I-4$ & 2,4-diCl/ $/ \mathrm{CH}_{3}$ & 100 & 100 & 100 & 100 & 69 & 48 \\
\hline $5 I-5$ & $2-\mathrm{Me}-4-\mathrm{Cl} / \mathrm{CH}_{3}$ & 100 & 100 & 100 & 100 & 100 & 54 \\
\hline $5 I-6$ & $\mathrm{H} / \mathrm{CH}_{3}$ & 100 & 100 & 100 & 100 & 88 & 57 \\
\hline $5 \mathrm{I}-7$ & $4-\mathrm{F} / \mathrm{CH}_{2} \mathrm{CH}_{3}$ & 100 & 100 & 100 & 99 & 65 & 53 \\
\hline $5 \mathrm{I}-8$ & $2,4-\mathrm{diCl} / \mathrm{CH}_{2} \mathrm{CH}_{3}$ & 100 & 87 & 97 & 43 & 62 & 36 \\
\hline $5 I-9$ & $4-\mathrm{F} / \mathrm{CH}_{2} \mathrm{Ph}$ & 100 & 100 & 33 & 25 & 72 & 50 \\
\hline $5 I-10$ & $4-\mathrm{Cl} / \mathrm{CH}_{2} \mathrm{Ph}$ & 90 & 48 & 24 & 19 & 74 & 62 \\
\hline $5 \mathrm{I}-11$ & $4-\mathrm{Br} / \mathrm{CH}_{2} \mathrm{Ph}$ & 56 & 38 & 18 & 13 & 11 & 16 \\
\hline $5 \mathrm{I}-12$ & 2,4 -diCl $/ \mathrm{CH}_{2} \mathrm{Ph}$ & 98 & 70 & 33 & 20 & 26 & 23 \\
\hline $5 \mathrm{I}-13$ & $2-\mathrm{Me}-4-\mathrm{Cl} / \mathrm{CH}_{2} \mathrm{Ph}$ & 33 & 13 & 15 & 8 & 7 & 0 \\
\hline 5I-14 & $\mathrm{H} / \mathrm{CH}_{2} \mathrm{Ph}$ & 95 & 78 & 69 & 37 & 76 & 53 \\
\hline $5 I I-1$ & $4-\mathrm{F} / \mathrm{CH}_{3}$ & 99 & 92 & 50 & 49 & 40 & 36 \\
\hline $5 I I-2$ & $4-\mathrm{Cl} / \mathrm{CH}_{3}$ & 84 & 73 & 56 & 45 & 27 & 16 \\
\hline $5 \mathrm{II}-3$ & $4-\mathrm{Br} / \mathrm{CH}_{3}$ & 30 & 28 & 26 & 7 & 25 & 18 \\
\hline $5 I I-4$ & $2,4-\mathrm{diCl} / \mathrm{CH}_{3}$ & 16 & 18 & 18 & 15 & 23 & 20 \\
\hline $5 I I-5$ & $2-\mathrm{Me}-4-\mathrm{Cl} / \mathrm{CH}_{3}$ & 42 & 16 & 9 & 8 & 25 & 24 \\
\hline $5 \mathrm{II}-6$ & $4-\mathrm{F} / \mathrm{CH}_{2} \mathrm{CH}_{3}$ & 65 & 55 & 7 & 12 & 15 & 18 \\
\hline $5 \mathrm{II}-7$ & $2,4-\mathrm{diCl} / \mathrm{CH}_{2} \mathrm{CH}_{3}$ & 20 & 13 & 0 & 0 & 32 & 6 \\
\hline $5 \mathrm{II}-8$ & $4-\mathrm{F} / \mathrm{CH}_{2} \mathrm{Ph}$ & 24 & 8 & 30 & 10 & 24 & 21 \\
\hline $5 \mathrm{II}-9$ & $4-\mathrm{Cl} / \mathrm{CH}_{2} \mathrm{Ph}$ & 19 & 14 & 17 & 18 & 14 & 23 \\
\hline 5II-10 & $4-\mathrm{Br} / \mathrm{CH}_{2} \mathrm{Ph}$ & 10 & 0 & 11 & 1 & 5 & 8 \\
\hline 5II-11 & $2,4-\mathrm{diCl} / \mathrm{CH}_{2} \mathrm{Ph}$ & 37 & 14 & 27 & 26 & 38 & 32 \\
\hline 5II-12 & $2-\mathrm{Me}-4-\mathrm{Cl} / \mathrm{CH}_{2} \mathrm{Ph}$ & 5 & 0 & 0 & 0 & 10 & 33 \\
\hline Bismerthiazol $^{\mathrm{b}}$ & & 72 & 54 & 100 & 99 & 67 & 45 \\
\hline Kocide $3000^{b}$ & & 69 & 52 & 100 & 100 & 39 & 25 \\
\hline Thiodiazole-copper ${ }^{b}$ & & 69 & 35 & 50 & 35 & 65 & 47 \\
\hline
\end{tabular}

${ }^{a}$ Average of three replicates; ${ }^{b}$ The commercial agricultural antibacterial agents Bismerthiazol, Kocide 3000, and Thiodiazole-copper were used as positive control.

The compounds acting better than positive controls (Table 1) were further performed for dose response with lower gradient concentration for their $\mathrm{EC}_{50}$ values (Table 2). Compounds 5I-1-5I-7 revealed outstanding activity against $X$. oryzae with $\mathrm{EC}_{50}$ values of $0.45,1.44,1.67,0.72$, $1.67,1.86,0.52 \mu \mathrm{g} / \mathrm{mL}$ respectively, which are about $1 / 50-1 / 200$ fraction lower than $96.2 \mu \mathrm{g} / \mathrm{mL}$ displayed by Bismerthiazol. Meanwhile their EC $_{50}(1.97-20.51 \mu \mathrm{g} / \mathrm{mL})$ values against $R$. solanacearum, were shown to be much lower compared to the figure $45.91 \mu \mathrm{g} / \mathrm{mL}$ displayed by Kocide 3000 . Additionally, 5I-1-5I-7 inhibited the growth of X. axonopodis with $\mathrm{EC}_{50}$ values ranging from 24.89 to $96.83 \mu \mathrm{g} / \mathrm{mL}$. Although they were not as effective to the other two type of bacteria, but still superior to Bismerthiazol $(119.5 \mu \mathrm{g} / \mathrm{mL})$. More over $5 \mathrm{I}-3$ is the most active against X. axonopodis.

In particular, 5I-1 bearing 4-F substituted phenoxymethyl, acted best for combating X. oryzae and R. solanacearum with $\mathrm{EC}_{50}$ values of 0.45 and $1.97 \mu \mathrm{g} / \mathrm{mL}$ respectively, which were far better than three commercial positive controls. Besides, the compounds 5I-2, 5I-4, 5I-7 with $\mathrm{EC}_{50}$ values of 1.44, $0.72,0.52 \mu \mathrm{g} / \mathrm{mL}$ against $X$. oryzae and $13.42,20.51,7.75 \mu \mathrm{g} / \mathrm{mL}$ against $R$. solanacearum, respectively, appeared to be promising bactericides against plant bacterial diseases. 
Table 2. Antibacterial Activity of Compounds 5I-1-5I-7 against X. oryzae, R. solanacearu, and X. axonopodis ${ }^{a}$.

\begin{tabular}{|c|c|c|c|c|c|c|c|c|c|}
\hline \multirow{2}{*}{ Compd. } & \multicolumn{3}{|c|}{ X. oryzae } & \multicolumn{3}{|c|}{ R. solanacearum } & \multicolumn{3}{|c|}{ X. axonopodis } \\
\hline & $\mathrm{EC}_{50}(\mu \mathrm{g} / \mathrm{mL})$ & Regression Equation & $\mathbf{r}$ & $\mathrm{EC}_{50}(\mu \mathrm{g} / \mathrm{mL})$ & Regression Equation & $\mathbf{r}$ & $\mathrm{EC}_{50}(\mu \mathrm{g} / \mathrm{mL})$ & Regression Equation & $\mathbf{r}$ \\
\hline $5 \mathrm{I}-1$ & $0.45 \pm 0.06$ & $y=0.90 x+5.32$ & 0.88 & $1.97 \pm 0.23$ & $y=2.25 x+4.34$ & 0.98 & $80.46 \pm 5.38$ & $y=0.99 x+2.77$ & 0.96 \\
\hline $5 \mathrm{I}-2$ & $1.44 \pm 0.18$ & $y=2.73 x+4.57$ & 0.93 & $13.42 \pm 1.54$ & $y=2.79 x+1.86$ & 0.92 & $31.35 \pm 3.56$ & $y=1.95 x+2.09$ & 0.98 \\
\hline $5 I-3$ & $1.67 \pm 0.22$ & $y=2.96 x+4.40$ & 0.97 & $19.61 \pm 0.98$ & $y=1.44 x+3.14$ & 0.93 & $24.89 \pm 2.52$ & $y=1.52 x+2.87$ & 0.95 \\
\hline $5 I-4$ & $0.72 \pm 0.15$ & $y=2.28 x+5.33$ & 0.89 & $20.51 \pm 1.56$ & $y=2.18 x+2.14$ & 0.98 & $49.05 \pm 2.34$ & $y=1.40 x+2.58$ & 0.93 \\
\hline $5 I-5$ & $1.67 \pm 0.16$ & $y=2.78 x+4.38$ & 0.96 & $14.94 \pm 1.27$ & $y=3.43 x+0.97$ & 0.95 & $96.83 \pm 5.78$ & $y=1.36 x+2.29$ & 0.97 \\
\hline $5 \mathrm{I}-6$ & $1.86 \pm 0.23$ & $y=1.59 x+4.57$ & 0.90 & $13.55 \pm 2.12$ & $y=2.62 x+2.04$ & 0.91 & $85.02 \pm 4.32$ & $y=1.06 x+2.96$ & 0.96 \\
\hline $5 I-7$ & $0.52 \pm 0.16$ & $y=0.99 x+5.28$ & 0.96 & $7.75 \pm 1.01$ & $y=1.04 x+4.08$ & 0.99 & $52.23 \pm 2.14$ & $y=1.67 x+2.14$ & 0.97 \\
\hline Bismerthiazol $^{\mathrm{b}}$ & $92.61 \pm 2.15$ & $y=1.50 x+2.05$ & 0.98 & $59.69 \pm 2.56$ & $y=1.21 x+2.84$ & 0.98 & $119.5 \pm 5.1$ & $y=1.50 x+1.82$ & 0.98 \\
\hline Kocide $3000^{\mathrm{b}}$ & $101.60 \pm 5.12$ & $y=160 x+1.80$ & 0.99 & $45.91 \pm 6.6$ & $y=4.87 x-3.10$ & 0.98 & $>200$ & / & / \\
\hline Thiodiazole-copper ${ }^{b}$ & $121.82 \pm 3.59$ & $y=1.54 x+1.79$ & 0.98 & $>200$ & / & / & $107.04 \pm 1.96$ & $y=2.15 x+0.94$ & 0.98 \\
\hline
\end{tabular}

${ }^{\mathrm{a}}$ The statistical analysis was conducted by ANOVA method at the condition of equal variances assumed $(p>0.05)$ and equal variances not assumed $(p<0.05){ }^{\mathrm{b}}$ The commercial

agricultural antibacterial agents Bismerthiazol, Kocide 3000, and Thiodiazole-copper were used as positive control. 


\subsection{In Vivo Antibacterial Activity}

Having established outstanding bactericidal activity of 5I-1, 5I-2, 5I-4 in vitro, we further explored their antibacterial potency in vivo against rice bacterial leaf blight via the leaf-cutting method [22,23] under greenhouse condition at a concentration of $200 \mu \mathrm{g} / \mathrm{mL}$. Bismerthiazol and Thiodiazole-copper served as positive controls for this investigation. It was observed that all inoculated plants in 14 days exhibited blight symptoms with 100\% morbidity. Plants for blank control (no bacteria inoculations) appeared absence of bacterial infection throughout the testing time. The plants for negative control (inoculated but treated with no compounds) showed severe bacterial blight symptoms with about $20.0 \mathrm{~cm}$ long and spreading blight lesions. While the plants treated with tested compounds were relatively healthy and had obvious shorter lesions ranged from 1.9 to $4.9 \mathrm{~cm}$. $5 \mathrm{I}-\mathbf{1}$ afforded a maximum of lesion reduction. It can be seen (Table 3) that, comparing to the untreated control, 5I-1, 5I-2 and 5I-4 reduced bacterial leaf blight incidence by $90.4 \%, 77.7 \%$ and $81.1 \%$ respectively, which were superior to that of Bismerthiazol (25.6\%) and Thiodiazole-copper (32.0\%).

Table 3. In vivo Inhibitory Effect of Testing Compounds against X. oryzae at $200 \mu \mathrm{g} / \mathrm{mL}$.

\begin{tabular}{cccc}
\hline \multirow{2}{*}{ Compd. } & \multicolumn{3}{c}{ 14 Days after Spraying } \\
\cline { 2 - 4 } & Morbidity (\%) $^{\mathbf{c}}$ & Disease Index & Protective Efficiency (\%) $^{\mathbf{d}}$ \\
\hline 5I-1 & 100.0 & 15.6 & $90.4 \pm 2.8$ \\
5I-2 & 100.0 & 23.8 & $77.7 \pm 3.4$ \\
5I-4 & 100.0 & 17.5 & $81.1 \pm 1.9$ \\
Bismerthiazol & 100.0 & 60.0 & $25.6 \pm 4.4$ \\
Thiodiazole-copper $^{\text {CK1 }}{ }^{\text {a }}$ & 100.0 & 55.6 & $32.0 \pm 3.0$ \\
CK2 $^{\text {b }}$ & 0.0 & 0.0 & $100.0 \pm 0.0$ \\
\hline
\end{tabular}

${ }^{a}$ CK1: blank control sample; ${ }^{b}$ CK2: negative control sample; ${ }^{c}$ Bacteria inoculation was successful and all inoculated plants were infected; ${ }^{\mathrm{d}}$ Statistical analysis was conducted via the ANOVA method at a condition of equal variances assumed $(p>0.05)$ and equal variances not assumed $(p<0.05)$.

\subsection{Structure-Activity Relationship (SAR) Analyses}

On the basis of the activity values shown in Tables 1 and 2, a preliminary conclusion of the structure-activity relationship could be deduced. First, the antibacterial studies with both series compounds against tested bacteria revealed that compounds 5I displayed significantly higher antibacterial activity than the corresponding 1,3,4-thiadiazole 5II. Apparently the presence of heterocyclic unit 1,3,4-oxadiazole was critical to achieve significant inhibitory effect. Thus, for example, 1,3,4-oxadiazole sulfones 5I-1-5I-7 may serve as more potent source of antibacterial compounds compared to their corresponding 1,3,4-thiadiazole derivatives 5II. The difference may lie in that the oxygen atom in oxadiazole is more electronegative but less bulky than sulfur atom in thiadiazole which causing different interaction with the surrounding residues. However, the strategy of oxygen-sulfur bioisosterism substitution may not necessarily lead to one way enhancement of structure bioactivity. For example, a similar trend was documented that presence of 1,3,4-oxadiazole moiety is more potential than 1,3,4-thiadiazole in imparting the antifungal activity [13]. While 1,3,4-thiadiazol-2(3H)-ones displayed much higher inhibition activity than the corresponding 1,3,4-oxadiazol-2(3H)-ones as human protoporphyrinogen oxidase inhibitors [24,25].

Further antibacterial tests on $X$. oryzae and $R$. solanacearum, have revealed that 4-substituted mono halogenated phenoxymethyl derivatives $\left(\mathrm{R}_{1}=4-\mathrm{Cl}, 4-\mathrm{F}, 4-\mathrm{Br}\right)$ exhibited significant antibacterial activity which appears to decrease with increase in the size of the halogen substituent. Thus the order follows the trend $5 \mathrm{I}-1-\mathrm{F})>5 \mathrm{I}-2(\mathrm{Cl})>\mathbf{5 I}-3(\mathrm{Br})$ indicating that 4-F substituted derivative is most favorable in imparting antibacterial activity. At this point, it is in line with the previous report $[13,15]$ that bulky groups are normally disfavored in similar structures. In addition, introduction of stronger electron-withdrawing substituents $(\mathrm{F}>\mathrm{Cl}>\mathrm{Br})$ in the para-position of the benzene ring might assist in enhancing antibacterial activity. Specifically, when compound $\mathbf{5 I}-\mathbf{6}\left(R_{1}=H\right)$ was concerned, it is not 
bound to be the most potent among the 4-halogenated compounds with taking account the above two factors.

With regard to the nature of $\mathrm{R}_{2}$ substituent attached to the sulfonyl unit, similar trend in terms of activity was noted with increase in size of the alkyl group: $\mathrm{CH}_{3}>\mathrm{CH}_{2} \mathrm{CH}_{3}>\mathrm{CH}_{2} \mathrm{Ph}$, which means that methyl-sulfonyl derivatives are most active. The ethyl-sulfonyl bearing oxadiazole showed potent antibacterial activity, close to but slightly lower than the corresponding methylated one. Whereas incorporation of relatively bulky benzyl group in the sulfonyl unit led to dramatic reduction of antibacterial activity. This trend has been amply demonstrated in the observed decreasing order of activity with two different series of halogen substituents e.g., 5I-1 > 5I-7 > 5I-9(R $1=$ F) and 5I-4 $>$ 5I-8 $>$ 5I-12 $\left(\mathrm{R}_{1}=2\right.$,4-di Cl$)$. A similar decreasing behavior of activity with growing size of alkyl group attached to the sulfonyl unit was also observed with 5II series of compounds wherein oxadiazole moiety is replaced by thiadiazole skeleton.

Finally when the results are compared with those of previously reported sulfone analogs (Table 4), where the positive controls were same and acted in identical level [4,14-16], compound 5I-1 provides an ideal example of being associated with exceptionally high activity against $X$. oryzae $(0.45 \mu \mathrm{g} / \mathrm{mL})$ and $R$. solanacearum $(1.67 \mu \mathrm{g} / \mathrm{mL})$. In this regard, 2-(4-fluorophenoxymethyl)5-(methylsulfonyl)-1,3,4-oxadiazole (5I-1) is even more potent than the previously reported fungicides such as 2-(4-fluorophenzyl)-5-(methylsulfonyl)-1,3,4-oxadiazole [16] and 2-(4-fluorobenzyl)-5(methylsulfonyl)-1,3,4-oxadiazole [15]. It worth to note that when the molecular weights are considered, the same mass concentration means lower molar concentration, for the present new compounds possess the higher molecular weight with an -O-, or $\mathrm{OCH}_{2}$ group added. Similar bioactive trend could be observed on 5I-2(4-Cl) or 5I-4(2,4-di Cl) with their corresponding analog bearing 2-(4-chlorophenyl) or 2-(2,4-dichlorobenyl) substituent on heterocyclic side chain. It can be further derived from earlier reported data and our present investigation (Table 4) that the nature of 2-substituent in the 1,3,4-oxadiazole ring also plays a significant role in the design of final desired structure. The antibacterial activity with 2-substituents appears to follow the trend: phenyl $<$ benzyl $<$ phenoxymethyl. The fact that the presence of substituted phenoxymethyl substituent at the 2-position of 1,3,4-oxadiazole moiety helps to enhance biological activity may be attributed to the improved structural flexibility offered by $\mathrm{sp}^{3}$-hybridized methylene $\left(-\mathrm{CH}_{2}-\right)$, which helps to combine the receptor protein of pathogenic bacteria [15]. Furthermore, in accordance with the prediction put forward by CoMSIA 3D-QSAR, hydrogen-bond interaction offered by the oxygen atom of the alkyl aryl ether in the designated region in between phenyl and heteroalkyl group could be responsible for the enhanced bioactivity [14]. At the same time the electron withdrawing ability of the aroxymethyl group makes the compound more potent by reducing electron density on the heterocyclic system and increasing structure flexibility and stability.

Table 4. The Contribution of 2-Substituents in 1,3,4-Oxadiazole Ring towards Antibacterial Activity.

\begin{tabular}{|c|c|c|c|c|}
\hline \multirow[t]{2}{*}{ Plant Bacteria } & & $\mathrm{EC}_{50}$ & 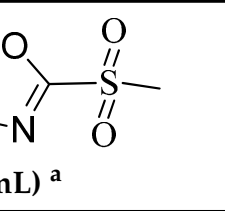 & \\
\hline & $\mathbf{R}$ & $X=$ No Atom & $\mathrm{X}=\mathrm{CH}_{2}$ & $\mathrm{X}=\mathrm{OCH}_{2}$ \\
\hline X. oryzae & $\begin{array}{c}\mathrm{F} \\
4-\mathrm{Cl} \\
\text { 2,4-di Cl}\end{array}$ & $\begin{array}{c}9.89 \pm 1.52^{16} \\
23.21 \pm 0.98^{16} \\
52.14 \pm 1.05^{16}\end{array}$ & $\begin{array}{c}1.07 \pm 0.68^{15} \\
12.23 \pm 1.45^{15} \\
1.96 \pm 0.99^{15}\end{array}$ & $\begin{array}{l}0.45 \pm 0.06(5 \mathrm{I}-1) \\
1.44 \pm 0.18(5 \mathrm{I}-2) \\
0.72 \pm 0.15(5 \mathrm{I}-4)\end{array}$ \\
\hline R. solanacearum & $\begin{array}{c}\mathrm{F} \\
4-\mathrm{Cl} \\
\text { 2,4-di Cl}\end{array}$ & $\begin{array}{c}8.29 \pm 0.56^{14} \\
120.90 \pm 2.6^{14} \\
16.55 \pm 1.12^{14}\end{array}$ & $\begin{array}{c}/^{\mathrm{b}} \\
\mathrm{NA}^{4} \\
59.9^{26}\end{array}$ & $\begin{array}{c}1.97 \pm 0.27(5 \mathrm{I}-\mathbf{1}) \\
13.42 \pm 1.54(\mathbf{5 I}-2) \\
20.51 \pm 1.56(\mathbf{5 I}-4)\end{array}$ \\
\hline
\end{tabular}

Note: ${ }^{a}$ The $\mathrm{EC}_{50}$ values of the positive control for the reference compounds and present compounds were determined under the same condition and are constantly in same level; b "/"means no reported data. NA, not active. Superscript $[4,14-16,26]$ are the references cited. 


\subsection{Phytotoxic Activity}

We preliminarily assessed the possible toxicity of $5 \mathrm{I}-\mathbf{1}, \mathbf{5 I}-\mathbf{2}, \mathbf{5 I}-4$ on rice germination and tobacco leaf inoculation $[27,28]$.

Initially, phytotoxic activity on tobacco leaves was assessed by infiltrating $50 \mu \mathrm{L}$ of a 50, 100, 200 and $300 \mu \mathrm{M}$ solution of each compound into the mesophylls of the leaves. Bismerthiazol was also included for comparison purposes, and as a reference control. After 4-day of innoculation, a brown necrotic area of around $0-0.3 \mathrm{~cm}$ diameter was observed (Figure 3). It appeared s no obvious difference among the inoculation spots. 5I-1, 5I-2, 5I-4 and Bismerthiazol appeared no or negligible phytotoxic effect on tobacco plant, with a necrosis between $0.2-0.3 \mathrm{~cm}$ at $300 \mu \mathrm{M}$ concentration. And there's no dose-response effect with a clear phytotoxicity increase from 50 to $300 \mu \mathrm{M}$ for all treatment.
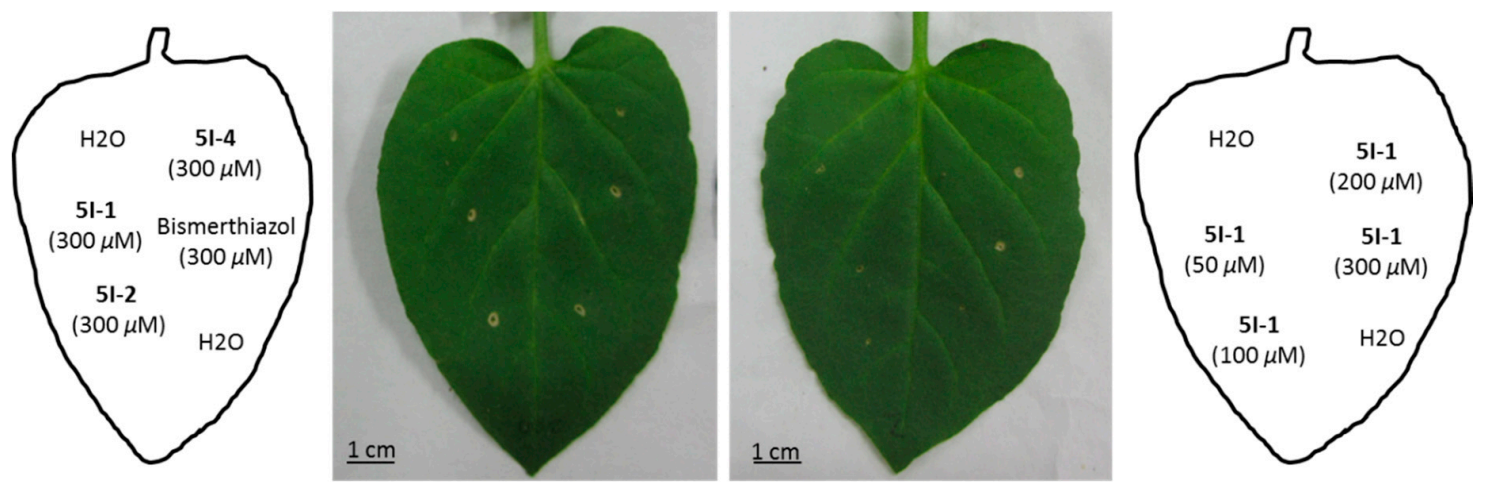

Figure 3. Phytotoxicity assay on tobacco plant representative examples of tobacco leaves four days after inoculation.

Further assays were carried out with rice germination test. Phytotoxic effects were quantified through shoot lengths of seedlings grown in the presence of decreasing concentrations of compounds (Table 5). Toxic effects were dose dependent. The high concentrations $(300 \mu \mathrm{M})$ of all chemicals severely affected seedling development (Figure 4). 5I-1, 5I-2 and 5I-4 were divergent on the phenotypic effects. Remarkably, 5I-4 severely inhibited both root growth and shoot development even at the lowest concentration $1 \mu \mathrm{M}$. 5I-2 predominantly inhibited root growth while allowing moderate shoot development. While, 5I-1, barely effected root growth or inhibited shoot development at concentration 1-100 $\mu \mathrm{M}$, similar to the appearance caused by Bismerthiazol. However, for the target synthetic compounds, phytotoxicity was only observed at concentrations many times higher than their bactericidal $\mathrm{EC}_{50}$ in terms of molar. While Bismerthiazol showed the phytotoxicity on $300 \mu \mathrm{M}$, which is around same level as bactericidal $\mathrm{EC}_{50} 119 \mu \mathrm{g} / \mathrm{mL}$ (about $333 \mu \mathrm{M}$ ).

Table 5. Phytotoxicity of target bactericidal compounds on rice germination ${ }^{\mathrm{a}}$.

\begin{tabular}{cccccc}
\hline \multirow{2}{*}{ Comp. } & \multicolumn{5}{c}{ Inhibition on Rice Germination Shoot Length (cm) } \\
\cline { 2 - 6 } & $\mathbf{1} \boldsymbol{\mu M}$ & $\mathbf{1 0} \boldsymbol{\mu M}$ & $\mathbf{5 0} \boldsymbol{\mu M}$ & $\mathbf{1 0 0} \boldsymbol{\mu} \mathbf{M}$ & $\mathbf{3 0 0} \boldsymbol{\mu M}$ \\
\hline $\mathbf{5 I - 1}$ & $3.8 \pm 0.5$ & $3.8 \pm 0.5$ & $3.7 \pm 0.6$ & $2.8 \pm 0.2$ & $0.1 \pm 0.1$ \\
$\mathbf{5 I - 2}$ & $3.7 \pm 0.6$ & $3.2 \pm 0.3$ & $3.2 \pm 0.6$ & $1.5 \pm 0.0$ & $0.5 \pm 0.1$ \\
$\mathbf{5 I - 4}$ & $1.7 \pm 0.3$ & $1.6 \pm 0.2$ & $1.0 \pm 0.1$ & $1.1 \pm 0.0$ & $0.5 \pm 0.0$ \\
Bismerthiazol $^{\mathrm{b}}$ & $4.2 \pm 0.6$ & $3.5 \pm 0.5$ & $3.7 \pm 0.4$ & $3.2 \pm 0.3$ & $0.1 \pm 0.1$ \\
$\mathrm{H}_{\mathbf{2}} \mathrm{O}$ & & & $4.6 \pm 0.2$ & \\
\hline
\end{tabular}

a Rice seeds germinated for seven days in $\mathrm{H}_{2} \mathrm{O}$ or increased concentrations of compounds. The size of rice germination shoot length $(\mathrm{cm})$ is considered as a measure of phytotoxicity. The numbers indicate confidence interval of the mean. ${ }^{\mathrm{b}}$ Antibacterial agents Bismerthiazol was used as comparative agent. 


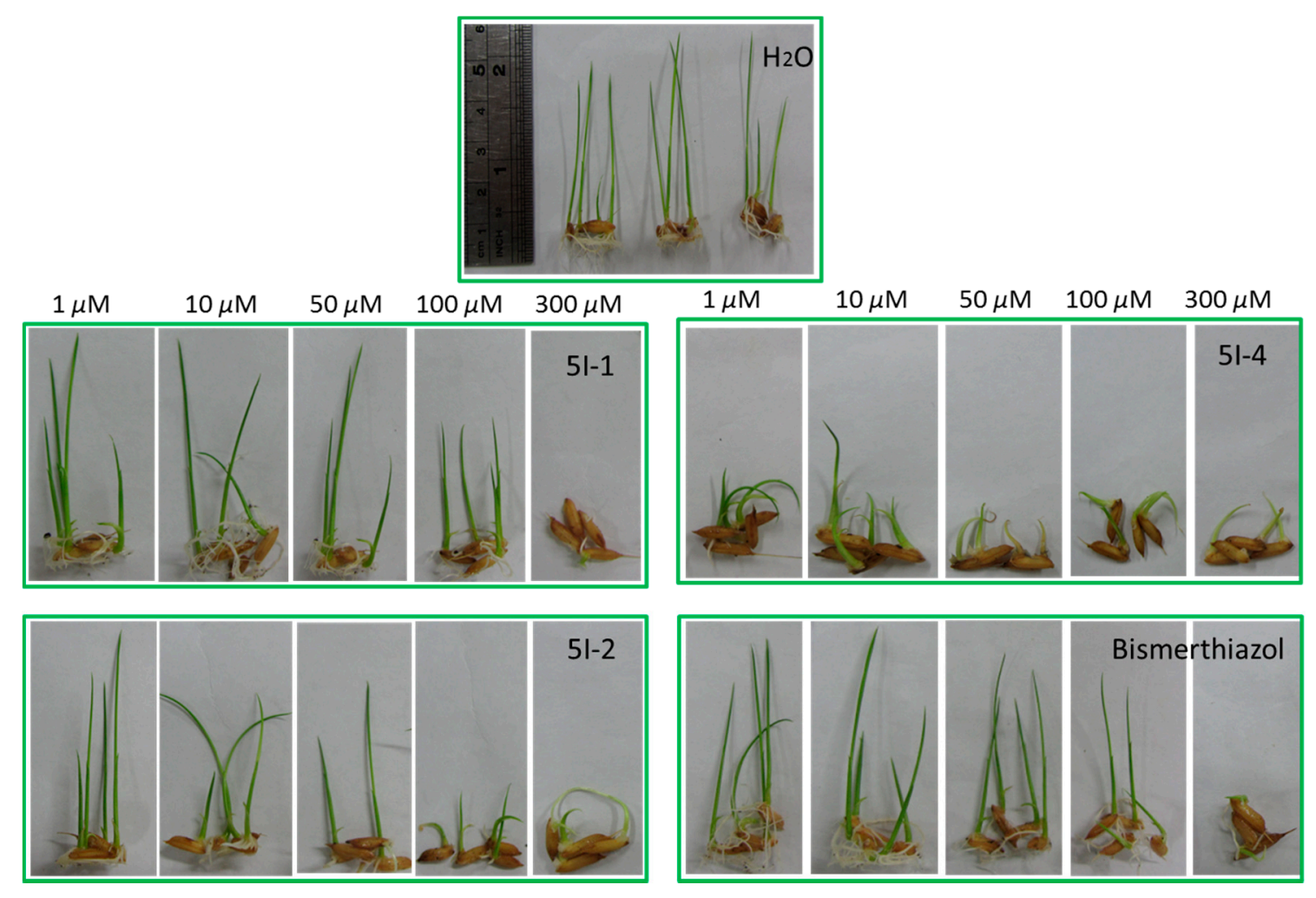

Figure 4. Phytotoxicity assay on rice seeds germination.

\section{Experimental}

\subsection{Chemicals and Instruments}

All the reagents and solvents were purchased from Aladdin (Shanghai, China) and used without further purification. The progress of the reactions and purity of compounds were assessed by thin-layer chromatography (TLC) with $\mathrm{GF}_{254}$ silica-gel precoated sheets (Merck KGaA, Darmstadt, Germany) using hexane/ethyl acetate as eluent; the melting points of the products were determined on an XT-4 binocular microscope (Beijing Tech Instrument Co., Beijing, China). ${ }^{1} \mathrm{H}$ and ${ }^{13} \mathrm{C} \mathrm{NMR} \mathrm{(solvent} \mathrm{CDCl}_{3}$ or DMSO- $d_{6}$ ) spectral studies were conducted on a JEOL-ECX 500 NMR spectrometer (JEOL, Tokyo, Japan) using TMS as internal standard. Elemental analysis was performed on an Elemental Vario-III $\mathrm{CHN}$ analyzer (Elementar Analysensysteme $\mathrm{GmbH}$, Hanau, Germany). Mass spectral studies were conducted on an Agilent LC/MSD Trap VL (Agilent, Santa Clara, CA, USA) mass spectrometer.

\subsection{General Synthetic Procedure for the Target Compounds $\mathbf{5 I}$ and 5II}

The synthetic route to target compounds is shown in Figure 2 which has been designed partly based on previously reported methods [18-20].

\subsubsection{Synthesis of Substituted Phenoxyacetohydrazide (2) as Intermediate}

To an oven-dried round bottomed flask with a stirring bar was added a solution of substituted phenol (0.01 mol, 1 eq.) and $\mathrm{K}_{2} \mathrm{CO}_{3}$ (1.2 eq.) in $50 \mathrm{~mL}$ of dry DMF. Excess ethyl chloroacetate dissolved in $10 \mathrm{~mL}$ of DMF was then slowly added through a dropping funnel to the above solution. The resulting mixture was stirred at $90{ }^{\circ} \mathrm{C}$ for $5-6 \mathrm{~h}$. The reaction was quenched with saturated $\mathrm{NaCl}$ solution, then extracted with dichloromethane(DCM), washed with brine, dried over $\mathrm{MgSO}_{4}$ and then concentrated on a rotary evaporator affording methyl 2-phenoxyacetate 1 ( $80 \%-95 \%$ yield) which was used for the next step without further purification [17].This product $1(0.009 \mathrm{~mol}, 1 \mathrm{eq}$.$) was$ dissolved in $30 \mathrm{~mL}$ of ethanol and then placed in a round-bottomed flask equipped with a stirring bar; 
$80 \%$ of hydrazine hydrate $(0.018 \mathrm{~mol}, 2$ eq.) was slowly added to this mixture at room temperature through a dropping funnel. The resulting solution was heated up to reflux temperature and stirring was continued under this condition for another $6 \mathrm{~h}$. The reaction mixture was filtered through celite, the filtrate was washed with brine, dried over $\mathrm{MgSO}_{4}$, and then concentrated in vacuo. The crude phenoxyacetohydrazide 2 was used directly without further purification in the next step.

\subsubsection{Synthesis of the Key Intermediate 2-Thiol-5-Substituted-1,3,4-Oxadiazole/Thiadiazole (3)}

For $\mathrm{X}=\mathrm{O}(3 \mathrm{I})$, to a $100 \mathrm{~mL}$ three necked rounded-bottomed flask was added a solution of intermediate 2 ( 0.009 mol, 1 eq.) and $\mathrm{KOH}(0.0108 \mathrm{~mol}, 1.2$ eq.) in $50 \mathrm{~mL}$ absolute ethanol. This mixture was first digested and then a diluted solution carbon disulfide $(0.0108 \mathrm{~mol}, 1.2 \mathrm{eq})$ in $10 \mathrm{~mL}$ of absolute ethanol was slowly added. The resulting mixture was stirred for $1-2 \mathrm{~h}$ and then refluxed at $80{ }^{\circ} \mathrm{C}$ till a homogeneous solution was obtained [19]. The alcohol was removed under reduced pressure on a rotary evaporator. The solution was washed with added brine followed by treatment with dilute hydrochloric acid solution. The $\mathrm{pH}$ was adjusted to 5-6 when a precipitate appeared which was subsequently filtered to afford a white solid 5-(phenoxymethyl)-1,3,4-oxadiazole-2-thiol (3I) (yield $60 \%-75 \%$ ).

For $\mathrm{X}=\mathrm{S}$ (3II), to a $100 \mathrm{~mL}$ three necked rounded-bottomed flask was added a solution of intermediate 2 (0.009 mol, 1 eq.), and $\mathrm{KOH}(0.0108 \mathrm{~mol}, 1.2$ eq.) in $50 \mathrm{~mL}$ of absolute ethanol. This mixture was first digested and then a diluted solution carbon disulfide ( $0.0108 \mathrm{~mol}, 1.2 \mathrm{eq})$ in $10 \mathrm{~mL}$ of absolute ethanol was slowly added. The resulting mixture was stirred for $5-6 \mathrm{~h}$ and then filtered through celite. The filtrate was concentrated in vacuo. The crude potassium 2-(2-phenoxyacetyl) hydrazinecarbodithioate (2-3) was washed with absolute ethanol alcohol and used directly in the next step for the preparation of 3II. 2-3(0.01 mol) was crushed into small powder and then slowly added to $50 \mathrm{~mL} \mathrm{H}_{2} \mathrm{SO}_{4}(98 \%)$. An exothermic reaction ensued, the solution was stirred on an ice salt bath for $2 \mathrm{~h}$, and the temperature was kept temperature below $5{ }^{\circ} \mathrm{C}$ in order to control the violence of the reaction. The progress of the reaction was monitored by TLC; the reaction was quenched by adding crushed ice equivalent to $200 \mathrm{~mL}$ of water. A white precipitate appeared which was filtered and then washed with water. The solid was subsequently dissolved in $10 \% \mathrm{NaOH}$ solution and filtered again. The filtrate was then acidified with hydrochloric acid $(\mathrm{HCl})$ to afford a white solid which was filtered to obtain the desired 5-(phenoxymethyl)-1,3,4-thiadiazole-2-thiol 3II.

\subsubsection{Synthesis of the Intermediate 2-Thiol-5-Substituted-1,3,4-Oxadiazole/Thiadiazole (4)}

To a solution of 2-thiol-5-substituted-1, 3, 4-oxadiazole/thiadiazole 3 (2 mmol) and sodium hydroxide (2.4 mmol, 1.2 eq.) in water $(10 \mathrm{~mL})$, dimethyl sulfate/diethyl sulfate (2.4 mmol, $1.2 \mathrm{eq}$.) was added drop wise with constant stirring at room temperature. The reaction was monitored for its completion by thin layer chromatography (TLC), quenched with saturated $\mathrm{NaCl}$ solution, then extracted with dichloromethane $(3 \times 20 \mathrm{~mL})$. The solvent layer was washed with brine, dried over $\mathrm{Na}_{2} \mathrm{SO}_{4}$ and then concentrated on a rotary evaporator affording a yellow oil, 2-thiol-5-substituted-1, 3, 4 -oxadiazole/ thiadiazole (4) $(70 \%-80 \%$ yield).

\subsubsection{Synthetic Procedure for the Target Compounds 5}

A $50 \mathrm{~mL}$ three-neck round-bottom flask equipped with a magnetic stirrer was charged with intermediate 4 and glacial acetic acid $(15 \mathrm{~mL})$. The mixture was stirred for $10 \mathrm{~min}$ and then $7 \%$ potassium permanganate $\left(\mathrm{KMnO}_{4}, 5 \mathrm{mmol}\right)$ solution was slowly added with string at room temperature [20]. After the completion of the reaction (assessed by TLC), 10\% sodium bisulfite $\left(\mathrm{NaHSO}_{3}\right)$ solution was added to deoxidize the residual $\mathrm{KMnO}_{4}$. The reaction mixture were subsequently filtered and the solid obtained was washed with distilled water, dried under vacuum, and recrystallized from ethanol to give compounds 5 .

2-(4-Fluorophenoxymethyl)-5-(methylsulfonyl)-1,3,4-oxadiazole (5I-1). White acicular crystal; m.p.: 108-110 ${ }^{\circ} \mathrm{C} ;{ }^{1} \mathrm{H}-\mathrm{NMR}\left(500 \mathrm{MHz}, \mathrm{CDCl}_{3}\right) 3.50(\mathrm{~s}, 3 \mathrm{H}), 5.32(\mathrm{~s}, 2 \mathrm{H}), 7.12-6.89(\mathrm{~m}, 4 \mathrm{H}) ;{ }^{13} \mathrm{C}-\mathrm{NMR}\left(\mathrm{CDCl}_{3}\right.$, 
$125 \mathrm{MHz}) \delta: 42.2,61.6,112.7(\mathrm{~d}, J=46.1 \mathrm{~Hz}), 116.2,116.4(\mathrm{~d}, J=1.9 \mathrm{~Hz}), 116.5,120.0(\mathrm{~d}, J=1.0 \mathrm{~Hz})$, $155.5(\mathrm{~d}, J=468.7 \mathrm{~Hz}), 173.8,178.9$; Anal. calcd. for $\mathrm{C}_{10} \mathrm{H}_{9} \mathrm{FN}_{2} \mathrm{O}_{4} \mathrm{~S}: \mathrm{C}, 44.12 ; \mathrm{H}, 3.33 ; \mathrm{N}, 10.29$; found: C, 43.51; H, 3.53; N, 10.33. MS (ESI) $(m / z): 273.2 /[\mathrm{M}+\mathrm{H}]^{+}$.

2-((4-Chlorophenoxy)methyl)-5-(methylsulfonyl)-1,3,4-oxadiazole (5I-2). White solid; m.p.: 113-114 ${ }^{\circ} \mathrm{C}$; ${ }^{1} \mathrm{H}-\mathrm{NMR}\left(500 \mathrm{MHz}, \mathrm{CDCl}_{3}\right)$ \& 7.50-7.40 (m, 2H, Ar-H), 6.96-6.87 (m, 2H, Ar-H), 5.33 (s, 2H, -CH2-), $3.50\left(\mathrm{~s}, 3 \mathrm{H},-\mathrm{CH}_{3}\right) ;{ }^{13} \mathrm{C}-\mathrm{NMR}\left(125 \mathrm{MHz}, \mathrm{CDCl}_{3}\right) \delta 164.3,163.5,156.3,132.8,116.7,115.3,59.9,43.0$; Anal. calcd. for $\mathrm{C}_{10} \mathrm{H}_{9} \mathrm{ClN}_{2} \mathrm{O}_{4} \mathrm{~S}: \mathrm{C}, 36.23 ; \mathrm{H}, 3.21 ; \mathrm{N}, 8.42$. Found: $\mathrm{C}, 36.05 ; \mathrm{H}, 2.72 ; \mathrm{N}, 8.41$; MS (ESI) $(m / z): 357.2 /[\mathrm{M}+\mathrm{Na}]^{+}$.

2-((4-Bromophenoxy)methyl)-5-(methylsulfonyl)-1,3,4-oxadiazole (5I-3). White solid; m.p.: 97-99 ${ }^{\circ} \mathrm{C}$; ${ }^{1} \mathrm{H}-\mathrm{NMR}\left(500 \mathrm{MHz}, \mathrm{CDCl}_{3}\right) \delta 7.30$ (ddd, J = 8.8, 5.8, $\left.2.9 \mathrm{~Hz}, 2 \mathrm{H}, \mathrm{Ar}-\mathrm{H}\right), 6.98-6.90(\mathrm{~m}, 2 \mathrm{H}, \mathrm{Ar}-\mathrm{H})$, $5.52\left(\mathrm{~s}, 2 \mathrm{H},-\mathrm{CH}_{2}-\right), 3.48\left(\mathrm{~s}, 3 \mathrm{H},-\mathrm{CH}_{3}\right) ;{ }^{13} \mathrm{C}-\mathrm{NMR}\left(125 \mathrm{MHz}, \mathrm{CDCl}_{3}\right) \delta 172.5,170.1,155.6,129.95,129.9$, 127.9, 116.2, 116.2, 65.1, 43.1; Anal. calcd. for $\mathrm{C}_{10} \mathrm{H}_{9} \mathrm{BrN}_{2} \mathrm{O}_{4} \mathrm{~S}$ : C, 41.50; $\mathrm{H}, 3.71 ; \mathrm{N}, 9.71$. Found: $\mathrm{C}, 41.60$; $\mathrm{H}, 3.14 ; \mathrm{N}, 9.70$; MS (ESI) $(\mathrm{m} / \mathrm{z}): 311.2 /[\mathrm{M}+\mathrm{Na}]^{+}$.

2-((2,4-Dichlorophenoxy)methyl)-5-(methylsulfonyl)-1,3,4-oxadiazole (5I-4). White solid; m.p.: 123-124 ${ }^{\circ} \mathrm{C}$; ${ }^{1} \mathrm{H}-\mathrm{NMR}\left(500 \mathrm{MHz}, \mathrm{CDCl}_{3}\right) \delta 7.42(\mathrm{~d}, J=2.5 \mathrm{~Hz}, 1 \mathrm{H}, \mathrm{Ar}-\mathrm{H}), 7.25-7.22(\mathrm{~m}, 1 \mathrm{H}, \mathrm{Ar}-\mathrm{H}), 7.05$ $(\mathrm{d}, J=8.8 \mathrm{~Hz}, 1 \mathrm{H}, \mathrm{Ar}-\mathrm{H}), 5.39$ (s, 2H, -CH2-), $3.50\left(\mathrm{~s}, 3 \mathrm{H},-\mathrm{CH}_{3}\right) ;{ }^{13} \mathrm{C}-\mathrm{NMR}\left(125 \mathrm{MHz}, \mathrm{CDCl}_{3}\right) \delta$ 163.9, 163.6, 151.8, 130.8, 128.8, 128.1, 125.2, 116.4, 61.5, 43.0; Anal. calcd. for $\mathrm{C}_{10} \mathrm{H}_{8} \mathrm{Cl}_{2} \mathrm{~N}_{2} \mathrm{O}_{4} \mathrm{~S}$ : C, 37.54; H, 2.96; N, 8.97. Found: C, 37.17; H, 2.50; N, 8.67; MS (ESI) $(m / z): 323.3 /[\mathrm{M}+\mathrm{H}]^{+}$.

2-((4-Chloro-2-methylphenoxy)methyl)-5-(methylsulfonyl)-1,3,4-oxadiazole (5I-5). White solid; m.p.: 96-98 ${ }^{\circ} \mathrm{C} ;{ }^{1} \mathrm{H}-\mathrm{NMR}\left(500 \mathrm{MHz}, \mathrm{CDCl}_{3}\right) \delta 7.17(\mathrm{~d}, J=2.5 \mathrm{~Hz}, 1 \mathrm{H}, \mathrm{Ar}-\mathrm{H}), 7.14(\mathrm{dd}, J=8.6,2.6 \mathrm{~Hz}$, $1 \mathrm{H}, \mathrm{Ar}-\mathrm{H}), 6.86(\mathrm{~d}, J=8.6 \mathrm{~Hz}, 1 \mathrm{H}, \mathrm{Ar}-\mathrm{H}), 5.34\left(\mathrm{~s}, 2 \mathrm{H},-\mathrm{CH}_{2}-\right), 3.50\left(\mathrm{~s}, 3 \mathrm{H},-\mathrm{CH}_{3}\right), 2.23\left(\mathrm{~s}, 3 \mathrm{H}, \mathrm{Ar}-\mathrm{CH}_{3}\right)$; ${ }^{13} \mathrm{C}-\mathrm{NMR}\left(125 \mathrm{MHz}, \mathrm{CDCl}_{3}\right) \delta 164.6,163.4,154.1,131.2,129.6,127.5,126.7,112.9,60.3,43.0,16.1$; Anal. calcd. for $\mathrm{C}_{11} \mathrm{H}_{11} \mathrm{ClN}_{2} \mathrm{O}_{4} \mathrm{~S}$ : C, 43.91; H, 3.72; N, 9.35. Found: C, 43.64; H, 3.66; N, 9.25; MS (ESI) $(\mathrm{m} / \mathrm{z})$ : $325.2 /[\mathrm{M}+\mathrm{Na}]^{+}$.

2-(Methylsulfonyl)-5-(phenoxymethyl)-1,3,4-oxadiazole (5I-6). White solid; m.p.: 66-67 ${ }^{\circ} \mathrm{C} ;{ }^{1} \mathrm{H}-\mathrm{NMR}$ $\left(500 \mathrm{MHz}, \mathrm{CDCl}_{3}\right)$ ): 7.37-7.29 (m, 2H, Ar-H), $7.05(\mathrm{t}, J=7.4 \mathrm{~Hz}, 1 \mathrm{H}, \mathrm{Ar}-\mathrm{H}), 7.00-6.97(\mathrm{~m}, 2 \mathrm{H}, \mathrm{Ar}-\mathrm{H})$, $4.94\left(\mathrm{~s}, 2 \mathrm{H},-\mathrm{CH}_{2}-\right), 3.46\left(\mathrm{~s}, 3 \mathrm{H},-\mathrm{CH}_{3}\right) ;{ }^{13} \mathrm{C}-\mathrm{NMR}\left(125 \mathrm{MHz}, \mathrm{CDCl}_{3}\right)$ \&: 157.4, 154.8, 153.7, 129.8, 122.5, 115.0, 60.7, 49.0; Anal. calcd. for $\mathrm{C}_{10} \mathrm{H}_{10} \mathrm{~N}_{2} \mathrm{O}_{4} \mathrm{~S}: \mathrm{C}, 47.51 ; \mathrm{H}, 4.33 ; \mathrm{N}, 11.33$. Found: $\mathrm{C}, 47.24 ; \mathrm{H}, 3.96 ; \mathrm{N}$, 11.02; $\mathrm{MS}(\mathrm{ESI})(\mathrm{m} / \mathrm{z}): 277.3 /[\mathrm{M}+\mathrm{Na}]^{+}$.

2-(Ethylsulfonyl)-5-((4-fluorophenoxy)methyl)-1,3,4-oxadiazole (5I-7). White solid; m.p.: 106-108 ${ }^{\circ} \mathrm{C}$; ${ }^{1} \mathrm{H}-\mathrm{NMR}\left(500 \mathrm{MHz}, \mathrm{CDCl}_{3}\right) \delta 7.12-6.90(\mathrm{~m}, 4 \mathrm{H}), 5.32(\mathrm{~s}, 2 \mathrm{H}), 3.58(\mathrm{q}, J=7.4 \mathrm{~Hz}, 2 \mathrm{H}), 1.51$ $(\mathrm{t}, J=7.4 \mathrm{~Hz}, 3 \mathrm{H}) ;{ }^{13} \mathrm{C}-\mathrm{NMR}\left(125 \mathrm{MHz}, \mathrm{CDCl}_{3}\right) \delta 164.6,162.7,153.4,116.6,116.5,116.4,116.4,115.9,60.6$, 50.2, 6.9; Anal. calcd. for $\mathrm{C}_{11} \mathrm{H}_{11} \mathrm{FN}_{2} \mathrm{O}_{4} \mathrm{~S}: \mathrm{C}, 46.15 ; \mathrm{H}, 3.87 ; \mathrm{N}$, 9.79. Found: $\mathrm{C}, 45.35 ; \mathrm{H}, 3.84 ; \mathrm{N}, 9.85$; MS (ESI) $(m / z): 309.3 /[\mathrm{M}+\mathrm{Na}]^{+}$.

2-((2,4-Dichlorophenoxy)methyl)-5-(ethylsulfonyl)-1,3,4-oxadiazole (5I-8). White solid; m.p.: 88-89 ${ }^{\circ} \mathrm{C}$; ${ }^{1} \mathrm{H}-\mathrm{NMR}\left(500 \mathrm{MHz}, \mathrm{DMSO}-d_{6}\right) \delta 7.62(\mathrm{~d}, J=2.5 \mathrm{~Hz}, 1 \mathrm{H}, \mathrm{Ar}-\mathrm{H}), 7.39(\mathrm{dt}, J=21.6,5.7 \mathrm{~Hz}, 2 \mathrm{H}, \mathrm{Ar}-\mathrm{H})$, $5.66\left(\mathrm{~s}, 2 \mathrm{H},-\mathrm{CH}_{2}-\right), 3.74\left(\mathrm{q}, J=7.3 \mathrm{~Hz}, 2 \mathrm{H},-\mathrm{CH}_{2} \mathrm{CH}_{3}\right), 1.26\left(\mathrm{t}, J=7.3 \mathrm{~Hz}, 3 \mathrm{H},-\mathrm{CH}_{3}\right) ;{ }^{13} \mathrm{C}-\mathrm{NMR}$ $\left(125 \mathrm{MHz}\right.$, DMSO- $\left.d_{6}\right) \delta 164.6,161.9,151.7,129.6,128.2,126.3,122.9,116.4,61.1,49.5,6.6$; Anal. calcd. for $\mathrm{C}_{11} \mathrm{H}_{10} \mathrm{Cl}_{2} \mathrm{~N}_{2} \mathrm{O}_{4} \mathrm{~S}$ : C, 39.49; H, 3.48; N, 8.65. Found: C, 39.18; H, 2.99; N, 8.31; MS (ESI) $(\mathrm{m} / \mathrm{z})$ : 359.1/[M+ Na $]^{+}$.

2-(Benzylsulfonyl)-5-((4-fluorophenoxy)methyl)-1,3,4-oxadiazole (5I-9). White sold; m.p.: $94-96{ }^{\circ} \mathrm{C}$; ${ }^{1} \mathrm{H}-\mathrm{NMR}\left(\mathrm{CDCl}_{3}, 500 \mathrm{MHz}\right)$ 8 7.42-7.23 (m, 5H), 7.06-6.88 (m, 4H), $5.21(\mathrm{~s}, 4 \mathrm{H}), 4.75(\mathrm{~s}, 4 \mathrm{H}) ;{ }^{13} \mathrm{C}-\mathrm{NMR}$ $\left(\mathrm{CDCl}_{3}, 125 \mathrm{MHz}\right) \delta 164.7,162.6,158.4(\mathrm{~d}, J=240.9 \mathrm{~Hz}), 153.3,131.2,130.0,129.3,124.6,116.5,116.3$ $(\mathrm{t}, J=4.1 \mathrm{~Hz}), 62.1,60.4$; Anal. calcd. for $\mathrm{C}_{16} \mathrm{H}_{13} \mathrm{FN}_{2} \mathrm{O}_{4} \mathrm{~S}: \mathrm{C}, 55.17 ; \mathrm{H}, 3.76 ; \mathrm{N}, 8.04$. Found: $\mathrm{C}, 55.17$; $\mathrm{H}, 3.66$; N, 8.29; MS (ESI) $(\mathrm{m} / z): 371.1 /[\mathrm{M}+\mathrm{Na}]^{+}$.

2-(Benzylsulfonyl)-5-((4-chlorophenoxy)methyl)-1,3,4-oxadiazole (5I-10). White solid; m.p.: 126-128 ${ }^{\circ} \mathrm{C}$; ${ }^{1} \mathrm{H}-\mathrm{NMR}\left(500 \mathrm{MHz}, \mathrm{CDCl}_{3}\right.$ ) 8 7.38-7.26 (m, 7H, Ar-H), 6.95-6.85 (m, 2H, Ar-H), $5.23\left(\mathrm{~s}, 2 \mathrm{H},-\mathrm{CH}_{2}-\right.$ ), 
4.75 (s, 2H, - $\left.\mathrm{CH}_{2}-\right) ;{ }^{13} \mathrm{C}-\mathrm{NMR}\left(125 \mathrm{MHz}, \mathrm{CDCl}_{3}\right) \delta 164.5,162.6,155.7,131.2,130.0,129.9,129.3,127.8$, 124.5, 116.2, 62.1, 59.8; Anal. calcd. for $\mathrm{C}_{16} \mathrm{H}_{13} \mathrm{ClN}_{2} \mathrm{O} 4_{\mathrm{S}}$ : C, 52.27; H, 4.13; N, 7.61. Found: C, 52.68; $\mathrm{H}, 3.59 ; \mathrm{N}, 7.68 ; \mathrm{MS}(\mathrm{ESI})(\mathrm{m} / z): 387.2 /[\mathrm{M}+\mathrm{Na}]^{+}$.

2-(Benzylsulfonyl)-5-((4-bromophenoxy)methyl)-1,3,4-oxadiazole (5I-11). White solid; m.p.: $142-143{ }^{\circ} \mathrm{C}$; ${ }^{1} \mathrm{H}-\mathrm{NMR}\left(500 \mathrm{MHz}, \mathrm{CDCl}_{3}\right) \delta$ 7.57-7.47 (m, 2H, Ar-H), 7.42-7.23 (m, 5H, Ar-H), 7.10-7.01 (m, 2H, $\mathrm{Ar}-\mathrm{H}), 5.55$ (s, 2H, - $\left.\mathrm{CH}_{2}-\right), 5.20$ (s, 2H, -CH2-); ${ }^{13} \mathrm{C}-\mathrm{NMR}\left(125 \mathrm{MHz}, \mathrm{CDCl}_{3}\right) \delta 164.4,162.7,156.2,132.8$, 131.2, 130.0, 129.3, 124.5, 116.7, 115.2, 62.1, 59.7; Anal. calcd. for $\mathrm{C}_{16} \mathrm{H}_{13} \mathrm{BrN}_{2} \mathrm{O}_{4} \mathrm{~S}: \mathrm{C}, 46.83 ; \mathrm{H}, 3.93$; $\mathrm{N}$, 6.70. Found: C, 46.96; H, 3.20; N, 6.84; MS (ESI) $(m / z)$ : 433.1/[M+Na $]^{+}$.

2-(Benzylsulfonyl)-5-((2,4-dichlorophenoxy)methyl)-1,3,4-oxadiazole (5I-12). White solid; m.p.: 121-122 ${ }^{\circ} \mathrm{C}$; ${ }^{1} \mathrm{H}-\mathrm{NMR}\left(500 \mathrm{MHz}, \mathrm{CDCl}_{3}\right) \delta 7.68(\mathrm{~d}, J=2.6 \mathrm{~Hz}, 1 \mathrm{H}, \mathrm{Ar}-\mathrm{H}), 7.46(\mathrm{dd}, J=8.9,2.6 \mathrm{~Hz}, 1 \mathrm{H}, \mathrm{Ar}-\mathrm{H})$, 7.40-7.29 (m, 6H, Ar-H), $5.67\left(\mathrm{~s}, 2 \mathrm{H},-\mathrm{CH}_{2}-\right), 5.21\left(\mathrm{~s}, 2 \mathrm{H},-\mathrm{CH}_{2}-\right) ;{ }^{13} \mathrm{C}-\mathrm{NMR}\left(125 \mathrm{MHz}, \mathrm{CDCl}_{3}\right) \delta$ 164.6, 162.0, 151.6, 131.3, 129. 7, 129.3, 128.7, 128.2, 126.2, 125.7, 122.8, 116.0, 60.7, 60.5; Anal. calcd. for $\mathrm{C}_{16} \mathrm{H}_{12} \mathrm{Cl}_{2} \mathrm{~N}_{2} \mathrm{O}_{4} \mathrm{~S}$ : C, 48.39; H, 3.43; N, 7.32. Found: C, 48.13; H, 3.03; N, 7.02; MS (ESI) $(\mathrm{m} / \mathrm{z}$ ): $399.4 /[\mathrm{M}+\mathrm{H}]^{+}$.

2-(Benzylsulfonyl)-5-((4-chloro-2-methylphenoxy)methyl)-1,3,4-oxadiazole (5I-13). Yellow crystal; m.p.: 144-145 ${ }^{\circ} \mathrm{C} ;{ }^{1} \mathrm{H}-\mathrm{NMR}\left(500 \mathrm{MHz}, \mathrm{CDCl}_{3}\right) \delta 7.39-7.35(\mathrm{~m}, 1 \mathrm{H}, \mathrm{Ar}-\mathrm{H}), 7.32(\mathrm{~d}, J=1.4 \mathrm{~Hz}, 1 \mathrm{H}, \mathrm{Ar}-\mathrm{H})$, 7.31-7.29 (m, 2H, Ar-H), 7.27 (s, 2H, Ar-H), 7.26-7.24 (m, 1H, Ar-H), $7.11(\mathrm{~d}, J=8.8 \mathrm{~Hz}, 1 \mathrm{H}, \mathrm{Ar}-\mathrm{H})$, $5.55\left(\mathrm{~s}, 2 \mathrm{H},-\mathrm{CH}_{2}-\right), 5.21\left(\mathrm{~s}, 2 \mathrm{H},-\mathrm{CH}_{2}-\right), 2.17\left(\mathrm{~s}, 3 \mathrm{H}, \mathrm{Ar}-\mathrm{CH}_{3}\right) ;{ }^{13} \mathrm{C}-\mathrm{NMR}\left(125 \mathrm{MHz}, \mathrm{CDCl}_{3}\right) \delta 174.6$, 169.8, 165.8, 162.4, 154.6, 131.8, 130.9, 129.8, 129.4, 129.2, 127.1, 126.3, 125.93, 114.4, 61.0, 60.6, 16.2; Anal. calcd. for $\mathrm{C}_{17} \mathrm{H}_{15} \mathrm{ClN}_{2} \mathrm{O}_{4} \mathrm{~S}$ : C, 53.31; H, 4.23; N, 7.26. Found: C, 53.90; H, 3.99; N, 7.39; MS (ESI) $(\mathrm{m} / \mathrm{z})$ : 401.2/[M+ Na $]^{+}$.

2-(Benzylsulfonyl)-5-(phenoxymethyl)-1,3,4-oxadiazole (5I-14). White solid; m.p.: $95-96{ }^{\circ} \mathrm{C} ;{ }^{1} \mathrm{H}-\mathrm{NMR}$ $\left(500 \mathrm{MHz}, \mathrm{CDCl}_{3}\right) \delta$ 7.40-7.24 (m, 7H, Ar-H), 7.06 (ddd, $\left.J=11.7,8.3,0.9 \mathrm{~Hz}, 3 \mathrm{H}, \mathrm{Ar}-\mathrm{H}\right), 5.53(\mathrm{~s}, 2 \mathrm{H}$, $\left.-\mathrm{CH}_{2}-\right), 5.20\left(\mathrm{~s}, 2 \mathrm{H},-\mathrm{CH}_{2}-\right)$; ${ }^{13} \mathrm{C}-\mathrm{NMR}\left(125 \mathrm{MHz}, \mathrm{CDCl}_{3}\right) \delta$ 165.4, 161.9, 157.0, 131.3, 129.7, 129.3, 128.8, 125.8, 122.0, 114.8, 60.5, 59.5; Anal. calcd. for $\mathrm{C}_{16} \mathrm{H}_{14} \mathrm{~N}_{2} \mathrm{O}_{4} \mathrm{~S}: \mathrm{C}, 58.52 ; \mathrm{H}, 4.60 ; \mathrm{N}$, 8.66. Found: C, 58.17; $\mathrm{H}, 4.27 ; \mathrm{N}, 8.48$; MS (ESI) $(\mathrm{m} / \mathrm{z}): 353.2 /[\mathrm{M}+\mathrm{Na}]^{+}$.

2-((4-Fluorophenoxy)methyl)-5-(methylsulfonyl)-1,3,4-thiadiazole (5II-1). White solid; m.p.: 107-109 ${ }^{\circ} \mathrm{C}$; ${ }^{1} \mathrm{H}-\mathrm{NMR}\left(500 \mathrm{MHz}, \mathrm{CDCl}_{3}\right) \delta$ 7.08-7.00 (m, 2H, Ar-H), 6.99-6.92 (m, 2H, Ar-H), $5.52\left(\mathrm{~s}, 2 \mathrm{H},-\mathrm{CH}_{2}-\right)$, $3.48\left(\mathrm{~s}, 3 \mathrm{H},-\mathrm{CH}_{3}\right) ;{ }^{13} \mathrm{C}-\mathrm{NMR}\left(125 \mathrm{MHz}, \mathrm{CDCl}_{3}\right) \delta 172.9,170.0,159.3,157.4,153.1,116.6,116.4,116.2$, 116.2, 65.5, 43.1; Anal. calcd. for $\mathrm{C}_{10} \mathrm{H}_{9} \mathrm{FN}_{2} \mathrm{O}_{3} \mathrm{~S}_{2}: \mathrm{C}, 41.64 ; \mathrm{H}, 3.49 ; \mathrm{N}, 9.93$. Found: $\mathrm{C}, 41.66 ; \mathrm{H}, 3.15 ; \mathrm{N}$, 9.72; $\mathrm{MS}(\mathrm{ESI})(\mathrm{m} / \mathrm{z}): 311.2 /[\mathrm{M}+\mathrm{Na}]^{+}$.

2-((4-Chlorophenoxy)methyl)-5-(methylsulfonyl)-1,3,4-thiadiazole (5II-2). White solid; m.p.: 119-120 ${ }^{\circ} \mathrm{C}$; ${ }^{1} \mathrm{H}-\mathrm{NMR}\left(500 \mathrm{MHz}, \mathrm{CDCl}_{3}\right) \delta$ 7.46-7.26 (m, 2H, Ar-H), 7.15 (dd, J = 5.8, 3.2 Hz, 2H, Ar-H), $5.73(\mathrm{~s}, 2 \mathrm{H}$, $\left.-\mathrm{CH}_{2}-\right)$, $3.66(\mathrm{~s}, 3 \mathrm{H},-\mathrm{CH} 3) ;{ }^{13} \mathrm{C}-\mathrm{NMR}\left(125 \mathrm{MHz}, \mathrm{CDCl}_{3}\right) \delta 172.7,170.6,156.5,130.0,126.3,117.4,64.9$, 43.6; Anal. calcd. for $\mathrm{C}_{10} \mathrm{H}_{9} \mathrm{ClN}_{2} \mathrm{O}_{3} \mathrm{~S}_{2}: \mathrm{C}, 39.53 ; \mathrm{H}, 3.32 ; \mathrm{N}, 9.20$. Found: $\mathrm{C}, 39.41 ; \mathrm{H}, 2.98 ; \mathrm{N}, 9.19$; MS (ESI) $(m / z): 327.1 /[\mathrm{M}+\mathrm{Na}]^{+}$.

2-((4-Bromophenoxy)methyl)-5-(methylsulfonyl)-1,3,4-thiadiazole (5II-3). Yellow crystal; m.p.: $114-115{ }^{\circ} \mathrm{C}$; ${ }^{1} \mathrm{H}-\mathrm{NMR}\left(500 \mathrm{MHz}, \mathrm{CDCl}_{3}\right) \delta$ 7.49-7.40 (m, 2H, Ar-H), 6.94-6.85 (m, 2H, Ar-H), $5.52\left(\mathrm{~s}, 2 \mathrm{H},-\mathrm{CH}_{2}-\right)$, $3.47\left(\mathrm{~s}, 3 \mathrm{H},-\mathrm{CH}_{3}\right) ;{ }^{13} \mathrm{C}-\mathrm{NMR}\left(125 \mathrm{MHz}, \mathrm{CDCl}_{3}\right) \delta 172.5,170.1,156.1,132.9,116.7,115.2,65.0,43.1$; Anal. calcd. for $\mathrm{C}_{10} \mathrm{H}_{9} \mathrm{BrN}_{2} \mathrm{O}_{3} \mathrm{~S}_{2}$ : C, 33.29; H, 2.99; N, 7.76. Found: C, 34.39; H, 2.60; N, 8.02; MS (ESI) $(m / z): 373.1 /[\mathrm{M}+\mathrm{Na}]^{+}$.

2-((2,4-Dichlorophenoxy)methyl)-5-(methylsulfonyl)-1,3,4-thiadiazole (5II-4). Yellow crystal; m.p.: 160-162 ${ }^{\circ} \mathrm{C} ;{ }^{1} \mathrm{H}-\mathrm{NMR}\left(500 \mathrm{MHz}, \mathrm{CDCl}_{3}\right) \delta 7.45(\mathrm{~d}, J=2.5 \mathrm{~Hz}, 1 \mathrm{H}, \mathrm{Ar}-\mathrm{H}), 7.25(\mathrm{dd}, J=8.8,2.5 \mathrm{~Hz}, 1 \mathrm{H}$, $\mathrm{Ar}-\mathrm{H}), 6.98(\mathrm{~d}, J=8.8 \mathrm{~Hz}, 1 \mathrm{H}, \mathrm{Ar}-\mathrm{H}), 5.57\left(\mathrm{~s}, 2 \mathrm{H},-\mathrm{CH}_{2}-\right), 3.49\left(\mathrm{~s}, 3 \mathrm{H},-\mathrm{CH}_{3}\right) ;{ }^{13} \mathrm{C}-\mathrm{NMR}\left(125 \mathrm{MHz}, \mathrm{CDCl}_{3}\right)$ $\delta$ 172.0, 170.3, 151.6, 130.8, 128.1, 124.6, 120.0, 115.1, 66.2, 43.2; Anal. calcd. for $\mathrm{C}_{10} \mathrm{H}_{8} \mathrm{Cl}_{2} \mathrm{~N}_{2} \mathrm{O}_{3} \mathrm{~S}_{2}$ : $\mathrm{C}$, 35.37; H, 2.81; N, 8.26. Found: C, 35.41; H, 2.38; N, 8.26; MS (ESI) $(m / z): 361.1 /[\mathrm{M}+\mathrm{Na}]^{+}$.

2-((4-Chloro-2-methylphenoxy)methyl)-5-(methylsulfonyl)-1,3,4-thiadiazole (5II-5). White solid; m.p.: 160-161 ${ }^{\circ} \mathrm{C} ;{ }^{1} \mathrm{H}-\mathrm{NMR}\left(500 \mathrm{MHz}, \mathrm{CDCl}_{3}\right) \delta 7.19(\mathrm{~d}, J=2.5 \mathrm{~Hz}, 1 \mathrm{H}, \mathrm{Ar}-\mathrm{H}), 7.16(\mathrm{dd}, J=8.6,2.6 \mathrm{~Hz}$, 
$1 \mathrm{H}, \mathrm{Ar}-\mathrm{H}), 6.81(\mathrm{~d}, J=8.6 \mathrm{~Hz}, 1 \mathrm{H}, \mathrm{Ar}-\mathrm{H}), 5.52\left(\mathrm{~s}, 2 \mathrm{H},-\mathrm{CH}_{2}-\right), 3.49\left(\mathrm{~s}, 3 \mathrm{H},-\mathrm{CH}_{3}\right), 2.27\left(\mathrm{~s}, 3 \mathrm{H}, \mathrm{Ar}-\mathrm{CH}_{3}\right)$; ${ }^{13} \mathrm{C}-\mathrm{NMR}\left(125 \mathrm{MHz}, \mathrm{CDCl}_{3}\right) \delta 172.9,170.0,153.8,131.3,129.0,127.4,126.8,112.3,65.2,43.1,16.3$; Anal. calcd. for $\mathrm{C}_{11} \mathrm{H}_{11} \mathrm{ClN}_{2} \mathrm{O}_{3} \mathrm{~S}_{2}: \mathrm{C}, 39.95 ; \mathrm{H}, 3.95 ; \mathrm{N}$, 8.57. Found: $\mathrm{C}, 41.44 ; \mathrm{H}, 3.48 ; \mathrm{N}, 8.79 ; \mathrm{MS}$ (ESI) $(m / z): 341.2 /[\mathrm{M}+\mathrm{Na}]^{+}$.

2-(Ethylsulfonyl)-5-((4-fluorophenoxy)methyl)-1,3,4-thiadiazole (5II-6). Yellow crystal; m.p.: 89-90 ${ }^{\circ} \mathrm{C}$; ${ }^{1} \mathrm{H}-\mathrm{NMR}\left(500 \mathrm{MHz}, \mathrm{CDCl}_{3}\right) \delta 7.04(\mathrm{dd}, J=9.1,8.1 \mathrm{~Hz}, 2 \mathrm{H}, \mathrm{Ar}-\mathrm{H}), 6.95(\mathrm{dd}, J=9.1,4.2 \mathrm{~Hz}, 2 \mathrm{H})$, $\mathrm{Ar}-\mathrm{H}, 5.51\left(\mathrm{~s}, 2 \mathrm{H},-\mathrm{CH}_{2}-\right), 3.60\left(\mathrm{q}, J=7.4 \mathrm{~Hz}, 2 \mathrm{H},-\mathrm{CH}_{2} \mathrm{CH}_{3}\right), 1.47(\mathrm{t}, J=7.4 \mathrm{~Hz}, 3 \mathrm{H},-\mathrm{CH} 3) ;{ }^{13} \mathrm{C}-\mathrm{NMR}$ (125 MHz, CDCl3) $\delta$ 172.9, 169.1, 159.3, 157.4, 153.2, 116.6, 116.4, 116.2, 116.2, 65.6, 50.3, 7.2; Anal. calcd. for C11H11FN2O3S2: C, 43.19; H, 4.09; N, 9.19. Found: C, 43.70; H, 3.67; N, 9.27; MS (ESI) $(\mathrm{m} / \mathrm{z}$ ): $325.2 /[\mathrm{M}+\mathrm{Na}]^{+}$.

2-((2,4-Dichlorophenoxy)methyl)-5-(ethylsulfonyl)-1,3,4-thiadiazole (5II-7). White solid; m.p.: 127-128 ${ }^{\circ} \mathrm{C}$; ${ }^{1} \mathrm{H}-\mathrm{NMR}\left(500 \mathrm{MHz}, \mathrm{CDCl}_{3}\right) \delta 7.45(\mathrm{~d}, J=2.5 \mathrm{~Hz}, 1 \mathrm{H}, \mathrm{Ar}-\mathrm{H}), 7.25\left(\mathrm{dd}, J=8.8,2.6 \mathrm{~Hz},{ }^{1} \mathrm{H}, \mathrm{Ar}-\mathrm{H}\right), 6.97$ $(\mathrm{d}, J=8.8 \mathrm{~Hz}, 1 \mathrm{H}, \mathrm{Ar}-\mathrm{H}), 5.57\left(\mathrm{~s}, 2 \mathrm{H},-\mathrm{CH}_{2}-\right), 3.61\left(\mathrm{q}, J=7.4 \mathrm{~Hz}, 2 \mathrm{H},-\mathrm{CH}_{2} \mathrm{CH}_{3}\right), 1.49(\mathrm{t}, J=7.4 \mathrm{~Hz}, 3 \mathrm{H}$, $\left.-\mathrm{CH}_{3}\right) ;{ }^{13} \mathrm{C}-\mathrm{NMR}\left(125 \mathrm{MHz}, \mathrm{CDCl}_{3}\right) \delta 172.1,169.3,151.6,130.7,128.4,128.1,124.6,115.1,66.3,50.2,7.2$; Anal. calcd. for $\mathrm{C}_{11} \mathrm{H}_{10} \mathrm{Cl}_{2} \mathrm{~N}_{2} \mathrm{O}_{3} \mathrm{~S}_{2}: \mathrm{C}, 37.18 ; \mathrm{H}, 3.37 ; \mathrm{N}, 7.96$. Found: $\mathrm{C}, 37.40 ; \mathrm{H}, 2.85 ; \mathrm{N}, 7.93$; MS (ESI) $(m / z): 375.1 /[\mathrm{M}+\mathrm{Na}]^{+}$.

2-(Benzylsulfonyl)-5-((4-fluorophenoxy)methyl)-1,3,4-thiadiazole (5II-8). White solid; m.p.: 132-134 ${ }^{\circ} \mathrm{C}$; ${ }^{1} \mathrm{H}-\mathrm{NMR}\left(500 \mathrm{MHz}, \mathrm{CDCl}_{3}\right) \delta 7.02(\mathrm{dd}, J=9.0,8.1 \mathrm{~Hz}, 2 \mathrm{H}, \mathrm{Ar}-\mathrm{H}), 6.89(\mathrm{dd}, J=9.2,4.2 \mathrm{~Hz}, 2 \mathrm{H}, \mathrm{Ar}-\mathrm{H})$, $5.46\left(\mathrm{~s}, 2 \mathrm{H},-\mathrm{CH}_{2}-\right), 4.79\left(\mathrm{~s}, 2 \mathrm{H},-\mathrm{CH}_{2}-\right) ;{ }^{13} \mathrm{C}-\mathrm{NMR}\left(125 \mathrm{MHz}, \mathrm{CDCl}_{3}\right) \delta 173.4,168.6,159.3,157.4,153.1$, 153.0, 131.3, 129.6, 129.2, 125.9, 116.6, 116.4, 116.2, 116.1, 65.5, 61.9; Anal. calcd. for $\mathrm{C}_{16} \mathrm{H}_{13} \mathrm{FN}_{2} \mathrm{O}_{3} \mathrm{~S}_{2}$ : C, 52.69; H, 3.89; N, 7.64. Found: C, 52.73; H, 3.60; N, 7.69; MS (ESI) $(m / z): 387.2 /[\mathrm{M}+\mathrm{Na}]^{+}$.

2-(Benzylsulfonyl)-5-((4-chlorophenoxy)methyl)-1,3,4-thiadiazole (5II-9). White solid; m.p.: 140-141 ${ }^{\circ} \mathrm{C}$; ${ }^{1} \mathrm{H}-\mathrm{NMR}\left(500 \mathrm{MHz}, \mathrm{CDCl}_{3}\right) \delta 7.33$ (ddd, $\left.J=5.6,3.5,1.6 \mathrm{~Hz}, 2 \mathrm{H}, \mathrm{Ar}-\mathrm{H}\right), 7.30-7.28(\mathrm{~m}, 3 \mathrm{H}, \mathrm{Ar}-\mathrm{H}), 7.25$ $(\mathrm{d}, J=1.7 \mathrm{~Hz}, 2 \mathrm{H}, \mathrm{Ar}-\mathrm{H}), 6.87(\mathrm{dd}, J=8.8,1.8 \mathrm{~Hz}, 2 \mathrm{H}, \mathrm{Ar}-\mathrm{H}), 5.47\left(\mathrm{~s}, 2 \mathrm{H},-\mathrm{CH}_{2}-\right), 4.79\left(\mathrm{~s}, 2 \mathrm{H},-\mathrm{CH}_{2}-\right)$; ${ }^{13} \mathrm{C}-\mathrm{NMR}\left(125 \mathrm{MHz}, \mathrm{CDCl}_{3}\right) \delta 173.1,168.7,155.5,131.3,129.9,129.6,129.2,127.8,125.8,116.2,65.0,61.9$; Anal. calcd. for $\mathrm{C}_{16} \mathrm{H}_{13} \mathrm{ClN}_{2} \mathrm{O}_{3} \mathrm{~S}_{2}$ : C, 50.92; $\mathrm{H}, 3.93 ; \mathrm{N}, 7.50$. Found: $\mathrm{C}, 50.46 ; \mathrm{H}, 3.44 ; \mathrm{N}, 7.36$; MS (ESI) $(m / z): 403.2 /[\mathrm{M}+\mathrm{Na}]^{+}$.

2-(Benzylsulfonyl)-5-((4-bromophenoxy)methyl)-1,3,4-thiadiazole (5II-10). White solid; m.p.: $147-148{ }^{\circ} \mathrm{C}$; ${ }^{1} \mathrm{H}-\mathrm{NMR}\left(500 \mathrm{MHz}, \mathrm{CDCl}_{3}\right) \delta$ 7.48-7.39 (m, 2H, Ar-H), 7.39-7.22 (m, 5H, Ar-H), 6.88-6.78 (m, 2H, $\mathrm{Ar}-\mathrm{H}), 5.47$ (s, 2H, -CH2-), 4.78 (s, 2H, -CH2-); ${ }^{13} \mathrm{C}-\mathrm{NMR}$ (125 MHz, CDCl3) $\delta$ 173.0, 168.7, 156.0, 132.8, 131.3, 129.6, 129.2, 125.8, 116.7, 115.1, 64.9, 61.9; Anal. Calcd for $\mathrm{C}_{16} \mathrm{H}_{13} \mathrm{BrN}_{2} \mathrm{O}_{3} \mathrm{~S}_{2}: \mathrm{C}, 45.37 ; \mathrm{H}, 3.47 ; \mathrm{N}$, 6.62. Found: C, 45.18; H, 3.08; N, 6.59; MS (ESI) $(m / z): 449.1 /[\mathrm{M}+\mathrm{Na}]^{+}$.

2-(Benzylsulfonyl)-5-((2,4-dichlorophenoxy)methyl)-1,3,4-thiadiazole (5II-11). White solid; m.p.: 124-125 ${ }^{\circ} \mathrm{C}$; ${ }^{1} \mathrm{H}-\mathrm{NMR}\left(500 \mathrm{MHz}, \mathrm{CDCl}_{3}\right)$ 8 7.43-7.41 (m, 1H, Ar-H), 7.37-7.27 (m, 5H, Ar-H), 7.23 (ddd, J = 8.8, 2.4, $1.7 \mathrm{~Hz}, 1 \mathrm{H}, \mathrm{Ar}-\mathrm{H}), 6.92(\mathrm{dd}, J=8.8,1.2 \mathrm{~Hz}, 1 \mathrm{H}, \mathrm{Ar}-\mathrm{H}), 5.52(\mathrm{~s}, 2 \mathrm{H},-\mathrm{CH} 2-), 4.79\left(\mathrm{~s}, 2 \mathrm{H},-\mathrm{CH}_{2}-\right) ;{ }^{13} \mathrm{C}-\mathrm{NMR}$ $\left(125 \mathrm{MHz}, \mathrm{CDCl}_{3}\right) \delta$ 172.5, 168.9, 151.5, 131.3, 130.7, 130.0, 129.2, 128.3, 128.0, 125.8, 124.53, 115.1, 66.1, 61.9; Anal. calcd. for $\mathrm{C}_{16} \mathrm{H}_{12} \mathrm{Cl}_{2} \mathrm{~N}_{2} \mathrm{O}_{3} \mathrm{~S}_{2}$ : C, 46.74; $\mathrm{H}, 3.28 ; \mathrm{N}, 6.80$. Found: $\mathrm{C}, 46.27 ; \mathrm{H}, 2.91 ; \mathrm{N}, 6.75$; MS (ESI) $(m / z): 437.1 /[\mathrm{M}+\mathrm{Na}]^{+}$.

2-(Benzylsulfonyl)-5-((4-chloro-2-methylphenoxy)methyl)-1,3,4-thiadiazole (5II-12). White solid; m.p.: 125-126 ${ }^{\circ} \mathrm{C} ;{ }^{1} \mathrm{H}-\mathrm{NMR}\left(500 \mathrm{MHz}, \mathrm{CDCl}_{3}\right) \delta$ 7.39-7.26 (m, 5H, Ar-H), 7.18-7.10 (m, 2H, Ar-H), 6.75 $(\mathrm{d}, J=8.6 \mathrm{~Hz}, 1 \mathrm{H}, \mathrm{Ar}-\mathrm{H}), 5.46\left(\mathrm{~s}, 2 \mathrm{H},-\mathrm{CH}_{2}-\right), 4.79\left(\mathrm{~s}, 2 \mathrm{H},-\mathrm{CH}_{2}\right), 2.19\left(\mathrm{~s}, 3 \mathrm{H}, \mathrm{Ar}-\mathrm{CH}_{3}\right) ;{ }^{13} \mathrm{C}-\mathrm{NMR}(125$ $\left.\mathrm{MHz}, \mathrm{CDCl}_{3}\right) \delta 173.4,168.5,153.7,131.3,131.2,129.6,129.2,129.0,127.3,126.8,125.87,112.3,65.1,61.9$, 16.2; Anal. calcd. for $\mathrm{C}_{17} \mathrm{H}_{15} \mathrm{ClN}_{2} \mathrm{O}_{3} \mathrm{~S}_{2}: \mathrm{C}$, 51.93; H, 4.02; N, 7.17. Found: $\mathrm{C}, 51.71 ; \mathrm{H}, 3.83 ; \mathrm{N}, 7.09$; MS (ESI) $(m / z): 417.2 /[\mathrm{M}+\mathrm{Na}]^{+}$. 


\subsection{X-ray Diffraction Analysis}

Crystal structure of compound 5II-9 is shown in Figure 5. Colorless crystal of compound 5II-9 $(0.12 \mathrm{~mm} \times 0.13 \mathrm{~mm} \times 0.13 \mathrm{~mm})$ was mounted on a quartz fiber with protection oil. Cell dimensions and intensities were measured at $293 \mathrm{~K}$ on an Xcalibur (Eos, Gemini) diffractometer with graphite monochromated $\mathrm{Cu} \mathrm{K} \alpha$ radiation $(\lambda=1.54184 \AA)$. A total of 23281 reflections were measured, of which 3130 were unique (Rint $=0.0728$ ) in the range of $4.66<\theta<67.23^{\circ}$ (h, -13 to 13; $\mathrm{k},-10$ to $5 ; 1,-40$ to 40 ), and 2142 observed reflections with $\mathrm{I}>2 \sigma$ (I) were used in the refinement on $\mathrm{F}^{2}$. The structure was solved by direct method with the SHELXTL-97 program. All of the non-H atoms were refined anisotropically by full-matrix least-squares to give the final $R=0.0459$ and $W R=0.0459$. All hydrogen atoms were computed and refined using a riding model. The atomic coordinates for 5II-9 have been deposited at the Cambridge Crystallographic Data Centre. CCDC 1008894 contains the supplementary crystallographic data for this paper.

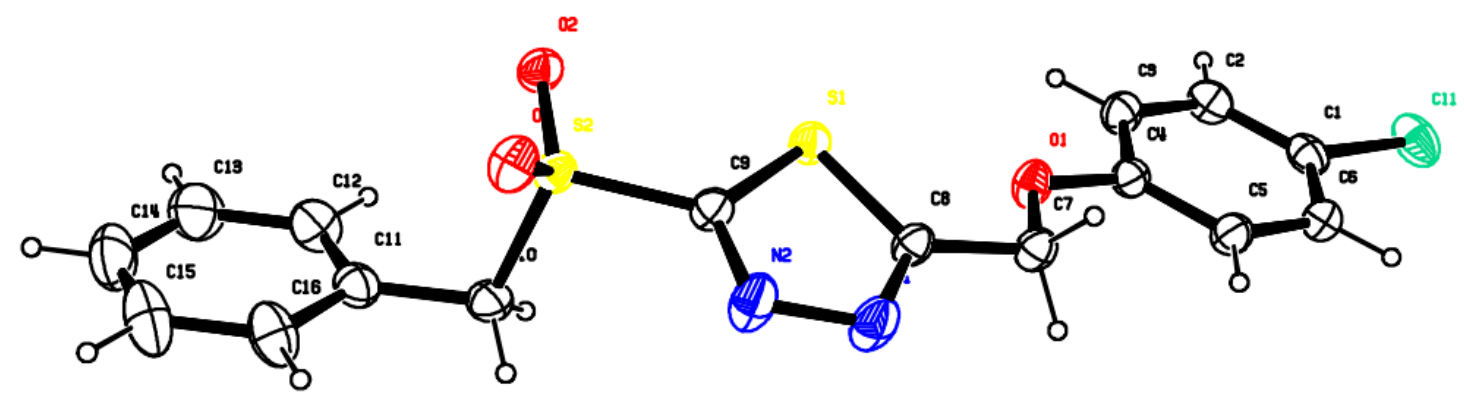

Figure 5. Crystal structure of compound 5II-9.

\subsection{Antibacterial Bioassay In Vitro}

The antibacterial activity against X. oryzae, $R$. solanacearum, X. axonopodis in vitro were evaluated according to the previously reported turbidmeter test [21]. The working solution concentration was set at 200 and $100 \mu \mathrm{g} / \mathrm{mL}$. Negative control(DMSO in sterile distilled water containing $0.1 \%$ Tween 20) were set up identically to test for absence of compound; Bismerthiazol (5,5'-(methylenediimino)bis-1,3,4-Thiadiazole-2(3H)-thione, 20\% WP, China Jiangxi Heyi Chem. Ind. Co., Ltd., Pengze, China), Kocide 3000 (Copper hydroxide, 46.1\%, DuPont, Wilmington, DE, USA)) and Thiodiazole-copper (2-amino-5-mercapto-1,3,4-thiadiazole-copper, 20\% SC, China Zhejiang Longwan Chem. Ind. Co., Ltd., Wenzhou, China) served as positive controls. Approximately $1 \mathrm{~mL}$ of stock solution was added to $4 \mathrm{~mL}$ nontoxic liquid medium nutrient broth (NB, $3 \mathrm{~g}$ of beef extract, $5 \mathrm{~g}$ of peptone, $1 \mathrm{~g}$ of yeast powder, $10 \mathrm{~g}$ of glucose, and $1000 \mathrm{~mL}$ of distilled water, $\mathrm{pH} 7.0$ to 7.2 ) in tubes. Then, approximately $40 \mu \mathrm{L} \mathrm{NB}$ culture media containing bacteria was added to $5 \mathrm{~mL}$ of NB solution containing compounds, DMSO or Kocide 3000, Thiodiazole-copper. Then, the inoculated test tubes were incubated at $30 \pm 1{ }^{\circ} \mathrm{C}$ with continuous shaking at $180 \mathrm{rpm}$ for $24 \mathrm{~h}$. The growth of bacterial culture was monitored with a spectrophotometer by measuring the optical density at $600 \mathrm{~nm}\left(\mathrm{OD}_{600}\right)$. The inhibitory rate of bacterial culture growth was calculated using the following equation:

$\mathrm{I}(\%)=(\mathrm{CK}-\mathrm{T}) / \mathrm{CK} \times 100$. Where "CK" implies the value of the corrected optical density of bacterial growth on untreated NB (negative control), and " $\mathrm{T}$ " means the value of corrected optical density of bacterial growth on treated NB; "I" denotes the inhibition rate.

The $\mathrm{EC}_{50}$ values of some well performed compounds were evaluated using the above-mentioned method under 5 different concentrations (e.g., 50, 25, 12.5, 6.25, $3.12 \mu \mathrm{g} / \mathrm{mL}$ for X. oryzae and R. solanacearum and $200,100,50,25,12.5 \mu \mathrm{g} / \mathrm{mL}$ for X. axonopodis). The average $\mathrm{EC}_{50}$ was computed from at least three separate analyses for growth inhibition with $\log _{10}$ probit analysis of SPSS 17.0. 


\subsection{Antibacterial Activity Bioassay In Vivo}

The in vivo preventive activities of compounds 5I-1, 5I-2, 5I-4 on lesion formation caused by $X$. oryzae in rice plant were evaluated according to the following procedure under greenhouse condition [22,23]. Rice seeds were soaked with water overnight and sown in small pots. Then the rooted seedlings were transplanted when they were 20 days old in net-house. The rice plants grown for 35-40 day bearing 3-4 leaves were ready to be treated. The tested compounds were dissolved in $120 \mu \mathrm{L}$ DMSO and diluted with $30 \mathrm{~mL} \mathrm{0.1 \%} \mathrm{Tween-20} \mathrm{to} \mathrm{the} \mathrm{final} \mathrm{concentration}$ of $200 \mu \mathrm{g} / \mathrm{mL}$. For comparison, parallel test were performed on Bismerthiazol, Thiodiazole-copper (positive control), no-compound (negative control), distilled water (blank control, absence of bacterial infection and compound treatment) with three replicates of each treatment. The seedlings on the 45 th day after sowing received foliar spray applications with $4 \mathrm{~mL}$ test compounds solution. One day later, the rice plants were clip inoculated with a bacterial suspension of $X$. oryzae culture $\left(10^{8} \mathrm{CFU} / \mathrm{mL}\right)$. Development of bacterial blight lesions was scored 14 days after the inoculation. The disease severity including infection rate and disease index was determined in terms incidence of lesion length and area. The percent disease suppression in the compounds treatment was calculated as compared to disease index of the untreated control in three independent experiments. And the data were analyzed for statistical significance using the least significant difference (LSD) test. Inhibitory effect afforded by the chemical treatment from that of the untreated control was calculated with the following formula:

Disease suppression $(\%)=(C-T) / C \times 100$, where $C$ implies disease index in untreated rice leaves; T means disease index in compound treated rice leaves.

\subsection{Phytotoxic Bioassay}

5I-1, 5I-2, 5I-4 were evaluated for their phytotoxicity on rice seed germination and tobacco plant as reference described $[27,28]$.

We initially assessed the possible toxicity on rice seed. For each treatment, a total of 4 surface-sterilized rice seeds (Fengyou Xiangzhan) were germinated in $200 \mu \mathrm{L}$ water or compounds solution at the appropriate concentration $(0,1,10,50,100$, and $300 \mu \mathrm{M})$ in each well of a 24-well plate for seven days. And $200 \mu \mathrm{L}$ double-distilled water was implemented in the third day. Five different concentrations of test compound, in triplicate, and reared in an incubator maintained at $28 \pm 1{ }^{\circ} \mathrm{C}$ with a photoperiod of $14 \mathrm{~h}$ light/10 h dark. Bismerthiazol was set as comparative agent. Seedling morphology was recorded and shoot length was measured. Phytotoxicity values in rice germination assays are given as minimal compound concentrations $(\mu \mathrm{M})$ causing significant alteration of shoot length.

Tobacco (Nicotiana benthamiana) plants were grown from seed in a heated glasshouse and used between 20 and 30 days old. $50 \mu \mathrm{L}$ chemically solution at 50, 100, 200 or $300 \mu \mathrm{M}$ were infiltrated into the mesophylls of fully expanded tobacco leaves (previously wounded with a needle) using a micropipette. The plants were kept at standard glasshouse conditions for seven days. Up to six independent inoculations were carried out in a single leaf, and at least three independent inoculations were performed for each compound and concentration, randomly distributed in different leaves and plants. Control infiltrations with water or comparative agent Bismerthiazol at the same molar concentration were performed. The appearance of symptoms on the leaves was followed for four days after infiltration. Toxicity was measured as the lesion diameter.

\section{Conclusions}

In summary, a series of novel aroxymethyl-1,3,4-oxadiazole/thiadiazole sulfone derivatives were obtained via embedding the substituted phenoxymethyl group into scaffold of heterocyclic substituted sulfone. The antibacterial activities were studied by the turbidimeter test against pathogens $X$. oryzae, $R$. solanacearum, and X. axonopodis, respectively. 1,3,4-Oxadiazole sulfones 5I are more potent as antibacterials compared to their corresponding 1,3,4-thiadiazole derivatives 5II and positive controls. Interestingly, as compared to commercial bactericides or our previous reported sulfone analogs (Table 4), compounds 5I-1-5I-7 possessed remarkably higher in vitro bactericidal 
activity against tested bacteria, which indicating that high-efficient target molecules were successfully obtained as we proposed. In vivo tests also revealed that 5I-1, 5I-2 and 5I-4 exhibited excellent preventive effects against $X$. axonopodis with inhibitory effect of $90.4 \%, 77.7 \%$ and $81.1 \%$ respectively. Compared to Bismerthiazol, 5I-1, 5I-2 exhibited no apparently phytotoxicity in tobacco leaves and rice seed germination with exception that 5I-4 highly suppressed both root and shoot development. The structure-activity relationship (SAR) analyses have suggested that aroxymethyl is found extremely useful to enhance the activity of the target structure and 1,3,4-oxadiazole sulfone derivatives bearing suitably substituted phenoxymethyl group may lead to the development of potent bactericides for crop protection.

Supplementary Materials: ${ }^{1} \mathrm{H}$ and ${ }^{13} \mathrm{C}$ NMR spectra of all the compounds are presented as Supporting Information; crystallographic data of compound 5II-9 (CCDC 1008894) for this paper could be obtained free of charge from The Cambridge Crystallographic Data Centre via www.ccdc.cam.ac.uk. The supplementary is available online at www.mdpi.com/1420-3049/22/1/64/s1.

Acknowledgments: This work was supported by the National Natural Science Foundation of China (20962005) and the Excellent Young Science and Technology Talent Cultivation Plan (201122).

Author Contributions: Jin conceived the project. Zhou \& Su contributed equally to this work. Su performed most of the experimental work while Zhou \& Liao implemented the biological test protocols. Qi prepared and participated in the phytotoxity assay. All authors analyzed the data and contributed to manuscript preparation. Zhou wrote the manuscript.

Conflicts of Interest: The authors declare no conflict of interest.

\section{References}

1. Spago, F.R.; Ishii Mauro, C.S.; Oliveira, A.G.; Beranger, J.P.O.; Cely, M.V.T.; Stanganelli, M.M.; Simionato, A.S.; San Martin, J.A.B.; Andrade, C.G.T.J.; Mello, J.C.P.; et al. Pseudomonas aeruginosa produces secondary metabolites that have biological activity against plant pathogenic Xanthomonas species. Crop Prot. 2014, 62, 46-54. [CrossRef]

2. Hayward, A.C. Biology and epidemiology of bacterial wilt caused by Pseudomonas solanacearum. Annu. Rev. Phytopathol. 1991, 29, 65-87. [CrossRef] [PubMed]

3. Milling, A.; Babujee, L.; Allen, C. Ralstonia solanacearum, extracellular polysaccharide is a specific elicitor of defense responses in wilt-resistant tomato plants. PLOS ONE 2011, 6, e15853. [CrossRef] [PubMed]

4. Xu, W.M.; Han, F.F.; He, M.; Hu, D.Y.; He, J.; Yang, S.; Song, B.A. Inhibition of tobacco bacterial wilt with sulfone derivatives containing an 1,3,4-Oxadiazole Moiety. J. Agric. Food Chem. 2012, 60, 1036-1041. [CrossRef] [PubMed]

5. Denny, T. Plant Pathogenic Ralstonia Species. Plant-Associated Bacteria; Springer: Dordrecht, The Netherlands, 2007; pp. 1-62.

6. Imazaki, I.; Nakaho, K. Pyruvate-amended modified SMSA medium: Imporved sensitivity for detection of Ralstonia solanacearum. J. Gen. Plant Pathol. 2010, 76, 52-61. [CrossRef]

7. Lo Cantore, P.; Shanmugaiah, V.; Iacbellis, N.S. Antibacterial activity of essential oil components and their potential use in seed disinfection. J. Agric. Food Chem. 2009, 57, 9454-9461. [CrossRef] [PubMed]

8. Wang, P.Y.; Zhou, L.; Zhou, J.; Wu, Z.B.; Xue, W.; Song, B.A.; Yang, S. Synthesis and antibacterial activity of pyridinium-tailored 2,5-substituted-1,3,4-oxadiazole thioether/sulfoxide/sulfone derivatives. Bioorg. Med. Chem. Lett. 2016, 26, 1214-1217. [PubMed]

9. Zhu, X.F.; Xu, Y.; Peng, D.; Zhang, Y.; Huang, T.T.; Wang, J.X. Detection and characterization of bismerthiazol-resistance of Xanthomonas oryzae, pv. oryzae. Crop Prot. 2013, 47, 24-29.

10. Zhou, X.J.; Wang, J.; Yang, Y.W.; Zhao, T.C.; Gao, B.D. Advances in tobacco bacterial wilt disease. Microbiol. China 2012, 39, 1479-1486.

11. Kleefeld, G.; Diehr, H.J.; Haas, W.; Dehne, H.W.; Brandes, W. Fungicidal Agents Based on Heterocyclic Substituted Sulfones. U.S. Patent 5,166,165, 27 May 1992.

12. Xu, W.M.; He, J.; He, M.; Han, F.F.; Chen, X.H.; Pan, Z.X.; Wang, J.; Tong, M.G. Synthesis and antifungal activity of novel sulfone derivatives containing 1,3,4-oxadiazole moieties. Molecules 2011, 16, 9129-9141. [CrossRef] [PubMed] 
13. Xu, W.M.; Yang, S.; Bhadury, P.; He, J.; He, M.; Gao, L.L.; Hu, D.Y.; Song, B.A. Synthesis and bioactivity of novel sulfone derivatives containing 2,4-dichlorophenyl substituted 1,3,4-oxadiazole/thiadiazole moiety as chitinase inhibitors. Pestic. Biochem. Phys. 2011, 101, 6-15. [CrossRef]

14. Li, P.; Yin, J.; Xu, W.M.; Wu, J.; He, M.; Hu, D.Y.; Yang, S.; Song, B.A. Synthesis, antibacterial activities, and 3D-QSAR of sulfone derivatives containing 1,3,4-oxadiazole moiety. Chem. Biol. Drug Des. 2013, 82, 546-556. [CrossRef] [PubMed]

15. Li, P.; Shi, L.; Yang, X.; Yang, L.; Chen, X.W.; Wu, F.; Shi, Q.C.; Xu, W.M.; He, M.; Hu, D.Y.; et al. Design, synthesis, and antibacterial activity against rice bacterial leaf blight and leaf streak of 2,5-substituted-1,3,4-oxadiazole/thiadiazole sulfone derivative. Bioorg. Med. Chem. Lett. 2014, 24, 1677-1680. [CrossRef] [PubMed]

16. Li, S.; Li, P.; Wang, W.L.; Gao, M.N.; Wu, Z.X.; Song, X.P.; Hu, D.Y. Antibacterial activity and mechanism of action of sulfone derivatives containing 1,3,4-oxadiazole moieties on rice bacterial leaf blight. Molecules 2015, 20, 11660-11675. [CrossRef] [PubMed]

17. Wei, T.B.; Chen, J.; Xu, R.; Zhang, Y.M. Synthesis, crystal structure and biological activities of 5-(2-aryloxymethylbenzimidazole-1-carbadehyde)-1,3,4-oxadiazole-2-thine. Chin. J. Org. Chem. 2009, 29, 758-763.

18. Sauter, H.; Steglich, W.; Anke, T. Strobilurins: Evolution of a New Class of Active Substances. Angew. Chem. Int. Ed. 1999, 38, 1328-1349. [CrossRef]

19. Chen, C.J.; Song, B.A.; Yang, S.; Xu, G.F.; Bhadury, P.S.; Jin, L.H.; Hu, D.Y.; Li, Q.Z.; Liu, F.; Xue, W. Synthesis and antifungal activities of 5-(3,4,5-trimethoxyphenyl)-2-sulfonyl-1,3,4-thiazole and 5-(3,4,5-trimethoxyphenyl)-2-sulfonyl-1,3,4-oxadiazole derivatives. Bioorg. Med. Chem. 2007, 15, 3981-3989. [CrossRef] [PubMed]

20. Chen, Q.; Zhu, X.L.; Jiang, L.L.; Liu, Z.M.; Yang, G.F. Synthesis, antifungal activity and comfa analysis of novel 1,2,4-triazolo[1,5-a]pyrimidine derivatives. Eur. J. Med. Chem. 2008, 43, 595-603. [CrossRef] [PubMed]

21. Dalgaard, P.; Ross, T.; Kamperman, L.; Neumeryer, K.; McMeekin, T.A. Estimation of bacterial growth rates from turbidimetric and viable count data. Int. J. Food Microbiol. 1994, 23, 391-404. [CrossRef]

22. Schaad, N.W.; Wang, Z.K.; Di, M.; Mcbeath, J.; Peterson, G.L.; Bonde, M.R. An improved infiltration technique to test the pathogenicity of Xanthomonas oryzae pv. oryzae in rice seedlings. Seed Sci. Technol. 1996, 24, 449-456.

23. Velusamy, P.; Immanuel, J.E.; Gnanamanickam, S.S.; Thomashow, L. Biological control of rice bacterial blight by plant-associated bacteria producing 2,4-diacetylphloroglucinol. Can. J. Microbiol. 2006, 52, 56-65. [CrossRef] [PubMed]

24. Jiang, L.L.; Tan, Y.; Zhu, X.L.; Wang, Z.F.; Zuo, Y.; Chen, Q.; Xi, Z.; Yang, G.F. Design, synthesis, and 3D-QSAR analysis of novel 1,3,4-oxadiazol-2(3H)-ones as protoporphyrinogen oxidase inhibitors. J. Agric. Food Chem. 2010, 58, 2643-2651. [CrossRef] [PubMed]

25. Zuo, Y.; Yang, S.G.; Jiang, L.L.; Hao, G.F.; Wang, Z.F.; Wu, Q.Y.; Xi, Z.; Yang, G.F. Quantitative structure-activity relationships of 1,3,4-thiadiazol-2(3H)-ones and 1,3,4-oxadiazol-2(3H)-ones as human protoporphyrinogen oxidase inhibitors. Bioorg. Med. Chem. 2012, 20, 296-304. [CrossRef] [PubMed]

26. Xu, W.M.; Song, B.A.; Yang, S.; Hu, D.Y.; Zeng, S.; He, M.; Li, P.; Yin, J. Antiacterial Activity of Sulfone Derivatives Containing 1,3,4-Oxadiazole Moiety. In Proceedings of the Collection of the 10th National Pesticide Research and Development Conference, Guiyang, China, 6 June 2014; pp. 44-48.

27. Vilà, S.; Badosa, E.; Montesinos, E.; Planas, M.; Feliu, L. Synthetic cyclolipopeptides selective against microbial, plant and animal cell targets by incorporation of d-amino acids or histidine. PLoS ONE 2016, 11, e0151639. [CrossRef] [PubMed]

28. Nadal, A.; Montero, M.; Company, N.; Badosa, E.; Messeguer, J.; Montesinos, L. Constitutive expression of transgenes encoding derivatives of the synthetic antimicrobial peptide bp100: Impact on rice host plant fitness. BMC Plant Biol. 2012, 12, 1-22. [CrossRef] [PubMed]

Sample Availability: Not available.

(c) 2016 by the authors; licensee MDPI, Basel, Switzerland. This article is an open access article distributed under the terms and conditions of the Creative Commons Attribution (CC-BY) license (http://creativecommons.org/licenses/by/4.0/). 